\title{
SOR MAURICIA DEL SANTÍSIMO SACRAMENTO, MONJA RECOLETA: EL ORIGINAL AUTÓGRAFO DE LA BIOGRAFÍA DE UNA MUJER MALTRATADA EN EL SIGLO XVII ${ }^{1}$
}

\author{
Laura SAMPEDRO REDONDO \\ UNED Asturias
}

\begin{abstract}
RESUMEN: En el Archivo Municipal de Gijón, se conservan dos cuadernillos manuscritos originales de la autobiografía escrita bajo obediencia de sus confesores, de Sor Mauricia del Santísimo Sacramento, Agustina Recoleta que acompaña a la Madre María de Santo Tomé, la fundadora de los conventos de Llanes y Gijón, a la fundación del convento de Gijón en 1668. Mujer casada antes de profesar, narra su vida desde su nacimiento, una vida llena de peripecias, marcada por el sufrimiento y el maltrato en su infancia y durante su matrimonio. Su vida fue publicada en un libro recopilatorio junto a otras autobiografías de la orden, pero estos cuadernos nos permiten conocer su relato original, libre de las correcciones y censuras de la versión oficial.
\end{abstract}

PALABRAS CLAVE: Sor Mauricia del Santísimo Sacramento, Agustinas Recoletas, mujer maltratada, autobiografía manuscrita.

ABSTRACT: Kept in the Municipal Archive of Gijón, there are two manuscript booklet containing the original autobiography, written under obedience, of Sor Mauricia del Santísimo Sacramento, Agustina Recoleta, who came along with Mother María de Santo Tomé, founder of the Llanes and Gijón, convents, to found the Gijón one, in 1668. Married woman before taking her vows as a nun, reports her life from the very exact moment of her birthday, a life full of adventures and miracles, signaled by abuse and maltreat not only during her childhood but along her married life. Her autobiography has been already published, included in a recopilatory book among other autobiographies of the same religious order, but this original notebooks allow us to know her original story, free of corrections and censorship of the oficial version.

KEYWORDS: Sor Mauricia del Santísimo Sacramento, Agustinas Recoletas, badtreated woman, manuscript autobiography.

\section{INTRODUCCIÓN}

En el curso de los trabajos llevados a cabo para la realización de nuestra tesis

${ }^{1}$ Recibido el 7 de septiembre y aceptado para su publicación el 28 de octubre de 2010. 
doctoral $^{2}$, y dentro de la documentación conservada en el Archivo Municipal de Gijón, revisamos el contenido de la caja número 139, en la que entre otros documentos privados sin clasificar ${ }^{3}$, encontramos dos cuadernillos de tamaño cuartilla, manuscritos por una mujer que dice que escribe su autobiografía bajo la obediencia de sus confesores y de la madre María de Santo Tomé, fundadora del convento de las Recoletas de Llanes.

De su lectura, cuya edición incluimos en este trabajo, no se desprende su nombre, pero establece claramente su pertenencia a la orden religiosa de las Agustinas Recoletas y su presencia en la fundación del convento en Gijón como una de las religiosas que acompañaron a la madre fundadora. Por otro lado, en su relato, desgrana un pasado como mujer casada que se desvela estremecedor por haber sido maltratada desde su infancia, primero por parte de la mujer que la crió y después por su marido.

El hecho de que inicie su relato haciendo constar que lo hace por obediencia, nos remite a las denominadas "autobiografías por mandato" ${ }^{4}$ de monjas, un género sin duda interesante dentro de la documentación de los siglos XVI y XVII por ser uno de los escasos focos de información directa de la voz femenina en esos siglos, aunque habitualmente "corregido" por la mano de sus superiores antes de ser publicado. Por ello, nos dirigimos en primer lugar a la recopilación publicada por las propia Orden de las Agustinas Recoletas.

$\mathrm{Y}$ en efecto, en un libro impreso en 1691, titulado Esclarecido solar de las religiosas recoletas de nuestro padre San Agustín y vidas de las Insignes hijas de sus conventos, compiladas por Fray Alonso de Villerino ${ }^{5}$, del que se conserva -al menos- un ejemplar en la Biblioteca Nacional y que recoge también la de la vida de Sor María de Santo Tomé, la fundadora, se recoge completa la vida de la Madre Mauricia del Santísimo Sacramento, cuyo relato coincide con los hechos narrados en los dos cuadernillos manuscritos conservados, si bien, de la lectura de los originales y su cotejo con la versión publicada impresa, se desprende que los cuadernillos serían el primero y el octavo de una serie total de diez, y que en la

2 L. SAMPEDRO REDONDO (2009). Escribanos y protocolos notariales de Gijón en el siglo XVI.

${ }^{3}$ L. SAMPEDRO REDONDo (2005) Membra disiecta de archivos señoriales en el Archivo Municipal de Gijón (1507 - 1580) Estudio y edición. Tesina Inédita.

${ }^{4}$ A. WEBER (2005). «Autobiografías por mandato: ¿Ego-documentos o textos sociales?» Cultura escrita \& Sociedad, $n^{\circ} 1$ pp. 116-119. Herpoel, S, (1987): Autobiografías por mandato: una escritura femenina en la España del Siglo de Oro.

5 A. Villerino (1691). Esclarecido solar de las religiosas recoletas de nuestro padre San Agustín. Y vidas de las insignes hijas de sus conventos Tomo II. pp.192 - 275. 
versión publicada impresa hay, respecto al original una multitud de correcciones de estilo y censuras relacionadas con datos sobre la procedencia de sus padres o las múltiples anécdotas del viaje de Llanes a Gijón para la fundación de su convento, probablemente encaminadas a frenar la espontaneidad del relato personal.

Una vez identificada como Sor Mauricia del Santísimo Sacramento, seguimos el rastro $^{6}$ de su existencia y su papel tan cercano a la fundadora Sor María de Santo Tomé, a quién acompaña primero desde Valladolid a Llanes en 1662, no como religiosa aún, sino como una de las doncellas que, junto con las tres monjas y dos legas o hermanas de obediencia acompañaron a la fundadora; y posteriormente, de Llanes a Gijón, ya como hermana de obediencia, tras tomar el hábito en el convento de Llanes en $1662^{7}$ para facilitar la fundación del Convento, tal y como ella misma afirma en su autobiografía. De lo leído resulta evidente que Sor Mauricia parece haber sido un pilar fundamental en la vida de su superiora ${ }^{8}$.

\section{PROCEDENCIA DEL MANUSCRITO}

También en el libro de Villerino encontramos, a modo de introducción de la autobiografía "oficial" de Mauricia, un testimonio valiosísimo para conocer cuál fue el camino que siguió la versión original manuscrita hasta llegar a ser corregida e impresa.

Se trata de una carta escrita en 1686 por Don Diego de Sierra y Valcarce, maestreescuela de la catedral de Salamanca ${ }^{9}$, dirigida a las monjas recoletas expresa que les hace llegar unos papeles -"joya preciosa"- para que los guarden en el Archivo de su Convento, especificando que son diez cuadernos de tamaño

${ }^{6}$ P. SANDín (1935). La Venerable Madre María de Santo Tomé, Reseña histórica, dones y hechos prodigiosos de la V. Santo Tomé, Agustina Recoleta y fundadora de los conventos de Llanes y de Gijón; Monasterio de El Escorial, Tipografía Agustiniana. AMLL. Protocolo notarial de Diego Posada Pariente, Caja 9, s,f. ; I. Gonzalez Sanchez, J. Díaz Alvarez (2005) «El monasterio de Madres Recoletas Agustinas Descalzas en Gijón: fundación y profesiones»en I. VIFORCos MARINAS, CAMPoS SANChEZ-Bordona,(Coord). Fundadores, fundaciones y espacios de vida conventual, nuevas aportaciones al monacato femenino .

${ }^{7}$ A. Villerino, o.c. p. 260.

${ }^{8}$ P. SANDín, o.c. p. 50, "por este tiempo dio en conocer la Madre a la que había de ser su ángel tutelar, hija suya y gran cooperadora en la fundación de sus conventos, Sor Mauricia del Smo. Sacramento, persona de sólida piedad y a quien la misma Madre preparó el camino para que entrara en su religión a pesar de ser entonces casada, cuando el señor lo dispusiere, lo que se complió en su dia; y además protegiola cuanto pudo de su marido, que fue gugador, vicioso y altanero y descargaba siempre sobre ella la furia de sus brutales sentimientos y hasta en cierta ocasión trató de matarla"

${ }^{9}$ A.VILLERINO, o.c. pp. 192,193 
cuartilla de los que, nueve son de mano de la madre Mauricia y contienen el relato de su vida, y el décimo relata los milagros de la fundadora del convento en Llanes, Sor María de Santo Tomé.

Don Diego de Sierra y Valcarce, manifiesta así mismo en su carta, que fue la propia Mauricia del Santísimo Sacramento quién se los hizo llegar años atrás -no dice cuantos-, sin que él lo solicitara, cuando él era Inquisidor en Cuenca, y que él tras someterlo a juicio de otros prelados y teólogos considera que es digna de dar ejemplo con su vida, pero que, debido a que está muy mal escrito por la "mala letra de monja", recomienda que lo copien -y de paso, aunque no lo dice, le pulan el estilo- para publicarlo, añadiendo que les envía los diez cuadernos por medio de una persona de su confianza, el jesuita, Alvaro Cienfuegos.

Es obvio que las monjas obedecieron la sugerencia y que otra persona, tal vez alguna monja del convento con mayor nivel cultural que Sor Mauricia, lo reescribió tratando de ser fiel al original aunque eliminando la espontaneidad de la primera mano, y algún que otro dato que debió parecerles poco discreto, como la procedencia de sus padres, o las peripecias y anécdotas del viaje del Llanes a Gijón que elimina por completo sustituyéndolas por una versión del recibimiento en Gijón, que a su vez -y esto es interesante- no está en el original manuscrito, por lo que consideramos que puede haber sido añadido a la versión oficial por mano de la "correctora" para completar la historia.

Lo que desconocemos en este momento, es la razón por la que esos dos pequeños "códices" ${ }^{10}$, primero y penúltimo de la serie acaban conservados en el archivo del ayuntamiento de Gijón o dónde están los demás, pues en el propio convento aseguran no conservar ninguno.

\section{RESUMEN DEL CONTENIDO DE LOS DOS CUADERNILLOS CONTENI- DOS}

En el primer cuadernillo, Mauricia comienza manifestando que lo hace por obediencia y que tiene sesenta años -dato que se omite en el impreso de la BNpara a contiuación proceder a relatar lo que conoce de su nacimiento, y lo que recuerda de su infancia maltratada por el ama de cría, así como su posterior educación en un convento y su matrimonio con un hombre que la maltrata, con quien tiene un hijo, y que la abandona, para acabar ella en Valladolid, sirviendo a un matrimonio de ancianos.

${ }^{10}$ Así se refieren a sí mismos según una nota manuscrita en la primera página. 
Todo el relato resulta estremecedor en cuanto a la violencia que recibió primero por parte del ama de cría que le pega, la intenta matar, quemar una pierna, etcétera, y después por su marido que la arruina y maltrata en toda clase de situaciones, intentando incluso matarla en dos ocasiones.

La mentalidad de la época y el hecho de ser una religiosa se transparentan en su narración, haciendo que el relato esté marcado por una fraseología extremadamente religiosa y que de forma reiterada exprese su agradecimiento a Dios y a los santos, con larguísimos circunloquios. Hay en su narración además, constantes alusiones a los milagros que le salvan la vida, que ella atribuye a que San Agustín la protege y a que, Dios, a pesar de ser ella una criatura sin valor, tiene para ella un destino. Tanto los agradecimientos como referencias son tan reiterativas que en ocasiones vuelven farragosa la lectura de corrido, sobremanera si lo que uno busca es sencillamente la peripecia de la vida de la mujer, desgajada de la mentalidad religiosa de la época y del propósito religioso con que se recopilan estas autobiografias de religiosas.

El segundo cuaderno conservado es el octavo de la serie completa. En él, narra entre otras vivencias, la salida del convento de Llanes con Sor María de Santo Tomé, fundadora de los conventos de Llanes y Gijón, y su viaje a Gijón, sobre el que desgrana una serie de peripecias más o menos graciosas y milagreras, y lo deslumbrada que quedó por el recibimiento -aunque no da nombres-.

No es una narración muy extensa, pero es importante destacar que destila un estado de ánimo muy diferente al del primer cuadernillo. Es sin duda una narradora muy expresiva y en esta parte trasluce una alegría que contrasta vivamente con el evidente sufrimiento que le provoca narrar la primera parte de su vida.

El resto de su vida, a falta de los otros cuadernillos originales, se puede seguir por la versión impresa del libro de Alonso Villerino, y desde luego hay que admitir que no permite que el interés decaiga, porque pasa por diferentes servicios, en distintas casas, su marido vuelve, de nuevo la arruina y finalmente decide dejarla para irse de peregrinación a Roma, gracias a la mediación de la Madre María de Santo Tomé, que intercede y media, quedando así Mauricia libre para ir con ella a Llanes.

\section{AUTOBIOGRAFÍAS DE MONJAS Y EL CASO DE MAURICIA DEL SANTÍSIMO SACRAMENTO.}

Queda claro por tanto que no estamos ante una autobiografía inédita. Su valor, insistimos, está en el hecho de que es parte de su versión original autógrafa. Y por su contenido, sin duda estremecedor por lo violento de su sufrimiento durante años, 
ha sido abordado en diversos estudios sobre autobiografías y literatura de género ${ }^{11}$, que en algún caso se lamentan de no haber podido disponer más que de la versión impresa y no del original.

Tal vez esa falta del original, que resta datos sin duda imprescindibles, sea la causa de que en algún estudio ${ }^{12}$ que aborda la biografía de Sor Mauricia, entre otras, no pueda establecer con claridad determinados aspectos como los límites de su vida y la fecha de redacción del manuscrito. Y en este sentido, el original manuscrito que aportamos en este artículo es sin duda de gran interés.

\section{RANGO DE FECHAS EN QUE NOS MOVEMOS PARA LA VIDA DE LA AUTORA.}

Herpoel situa la redacción del manuscrito entre "1659 (fecha en que toma el hábito) y 1670, año de su muerte" pero la misma autora alude a que "Afirma el editor que la monja estuvo ciega durante los últimos cuatro años de su vida, de lo que se deuce que la fecha límite de redacción es la de 1666, ya que la autobiografía estaba escrita de puño y letra de Mauricia" para terminar comentando "Por otro lado, la misma autobiografía refiere a los oficios que durante tres años desempeña en Gijón. La Vida es concluida, por lo tanto, en 1665 o $1666^{, 13}$

Pues bien, ese ajuste cronológico no puede ser correcto por varias razones. La fecha en la que Mauricia Pérez toma el hábito según consta en el protocolo notarial de Diego Posada de Llanes, notario de Llanes, es 1662 y no 1559 "El mismo año se acordó también la admisión de Mauricia Pérez, hija de Sebastián Pérez de Cáceres, vecinos de Coreses del Monte, Zamora, por una dote inferior a los mil ducados ${ }^{14 "}$.

En cuanto a la fecha final del manuscrito no puede ser 1666, habiendo estado tres años en Gijón y narrando como veremos el viaje que hicieron hasta allí, porque as monjas salen de Llanes y llegan a Gijón el 22 de septiembre de $1668^{15}$, fecha de

11 M. Diaz-Diocaretz, I.M. Zavala, M.M. CARRión (2000) Breve historia feminista de la Literatura Española(en Lengua Castellana. pg. 222 y 223; S. Herpoel, (1999) A la Zaga de Santa Teresa: Autobiografias por mandato, pp. 73,74

${ }^{12}$ S. Herpoel, (1999) A la Zaga de Santa Teresa..., o.c. pp. 73, 74

${ }^{13}$ S. Herpoel, (1999) A la Zaga de Santa Teresa..., o.c. pp. 73,74

${ }^{14}$ AMLL, Diego Posada Pariente, Protocolos notariales de Llanes, caja 9. s.f.

${ }^{15}$ P. SANDín, (1935). o.c. pp. 60,61 
la fundación del convento gijonés, y respecto al año de su fallecimiento tampoco puede ser el acotado por la autora 1670, por razones que veremos a continuación.

Tratando de acotar puntos de referencia, el relato empieza a escribirse en Llanes, Mauricia dice que tiene en ese momento sesenta años, asi lo afirma en la introducción que hace de sí misma al comienzo del relato, dato que se omite en la versión impresa.

En su relato Mauricia dice que al poco de nacer su hijo, teniendo ella unos 13 años, fue a visitarla Don Alfonso Márquez, Obispo de Segovia y esto por lo tanto tuvo que ser entre 1618 y 1621, fechas de su obispado en esa ciudad. Cabe deducir, por tanto, que pudo nacer hacia 1605 o 1607.

Los estudios mencionados establecen como posible fecha de su fallecimiento, el año 1670, pero creemos que esto no fue así, porque los mismos autores indican que parece que estuvo ciega los últimos cuatro años de su vida, y el convento de Gijón como dijimos se funda en 1668. Según esto, Mauricia, debía estar ciega o casi, cuando todavía estaba en Llanes. Sin embargo en el original ella relata deliciosas anécdotas del viaje de Llanes a Gijón, entre las que destaca una que hace referencia a que va montada en su propia yegua que se desboca al trote por entre las zarzas tras ver a uno de los caballos de la comitiva de Gijón, hasta el punto de que creyó que se mataría por una caída, de la que dice haberse librado por un milagro. Este episodio es eliminado totalmente sin la más mínima contemplación de la versión impresa-

Sin duda Mauricia era una mujer anciana para entonces, pues debía rondar en efecto los 60 años, pero viajó de Llanes a Gijón en yegua propia, y de viajar en esas condiciones, siendo mayor podría, pero además ciega... no sería lógico pensarlo y además su la letra es de una persona indudablemente anciana, pero lo escribe y ya está en Gijón cuando lo hace. Por lo tanto o no estuvo ciega los cuatro últimos años de su vida, o no murió en 1670 sino en una fecha posterior.

\section{ESTUDIO PRELIMINAR.}

\section{Análisis codicológico.}

El original conservado en la Caja 139 conservada en el Archivo Municipal de Gijón, son dos cuadernillos de tamaño cuartilla, cosidos por el frente del margen derecho. El primero está compuesto por un total de 57 páginas. Descontando la guarda del principio que está deteriorada y arrugada pero en blanco, todas las demás van escritas por el recto y por el vuelto, a excepción de tres planas -10r, 14r, 15r- que están en blanco. La escritura se dispone a renglón tendido, con margen 
muy escaso pero bien respetado en la parte izquierda del anverso y en la derecha del reverso, lo que sugiere que pudo ser redactado sobre el cuadernillo ya cosido. El segundo, mucho más breve, consta de 24 páginas, está cosido de la misma forma y escrito en su totalidad salvo en la primera y en el reverso de la última.

El papel es grueso, grisáceo pálido y con consistencia. La tinta es parda, oxidada en algún caso, y en algunas planas deja un halo graso alrededor de determinadas letras que están más cargadas de tinta. En ambos cuadernos, la conservación, a excepción de la mencionada primera página de guarda del primero, es excelente, y si bien los bordes exteriores de las páginas pueden estar ligeramente mellados ello no afecta a la lectura. Por otro lado, aunque algunas planas presentan manchas de tinta o grasa, ninguna afecta al texto hasta volverlo ilegible, como tampoco llega a perforar el papel el óxido de la tinta.

\section{Análisis paleográfico}

La "mala letra de monja" a la que alude Valcarce en su carta a las monjas Recoletas cuando les remite los cuadernillos manuscritos es una escritura de modulo mediano a grande, con un alfabeto humanístico, como corresponde ya a la época, segunda mitad del siglo XVII. Presenta un ductus inclinado a la derecha, con excepción de alguna letra que veremos al analizar su alfabeto.

En general no cierra bien los óvalos. Así las "a" quedan abiertas por la parte superior, con las "b" por la parte inferior, lo que hace que en ocasiones se confundan con una " $h$ ". También el óvalo de la "g" tiende a quedarle abierto por la parte superior.

El trazado más singular lo realiza con la "d" que recuerda a la "d" uncial de ojo abierto por la parte superior y astil curvándose de forma excesiva hacia la izquierda, casi llegando de nuevo a la altura del ovalo del ojo en su curvatura.

Otra de sus letras más singulares es la "i" que traza de dos maneras, una como la caligráfica itálica con su punto encima o con una raya, y otra como si fuera el número "I" romano, solo que con el remate superior separado -como si quisera poner el punto habitual pero lo convirtiera en una raya-. Utiliza una $\mathrm{u}$ otra indistintamente en la mayoría de los casos, tanto cuando le corresponde, como para sustituir a la "y" -por ejemplo escribe "io" en vez de "yo".

La "s" es muy abierta, casi como el esquema de un rayo. Las "t" y las "r" se llegan a confundir entre sí en algún caso, porque alarga el trazo superior horizontal de la "r" hacia la izquierda, además de hacia la derecha. En tanto que en la "t" ese trasversal lo hace en dos trazos y no uno, como es habitual. 
Sor Mauricia del Santísimo Sacramento, Monja Recoleta: el original autógrafo....

Fotografía 1: plana del manuscrito original conservado en el Archivo Municipal de Gijón, Caja 139.

fezo-sina ber mele bend

- des za ban mas le torde

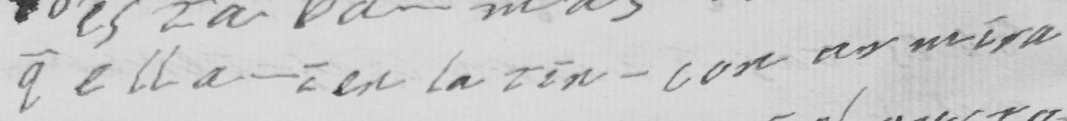

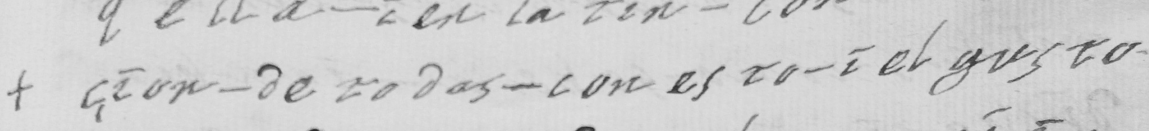

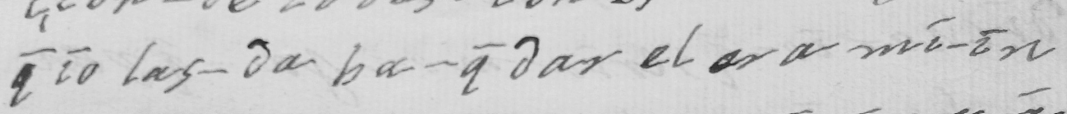

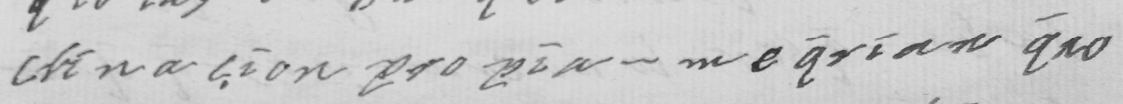
a bĩa-atra cusa-ícomo-me hian

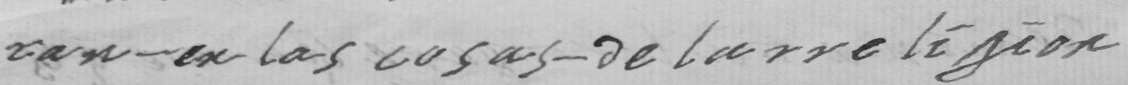

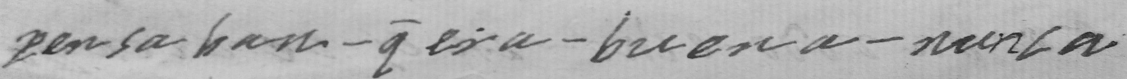
estabata cinosa-Ezodo-a Eurda ha

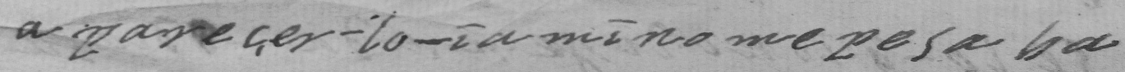
de q lopensase-comenclex zenex-e

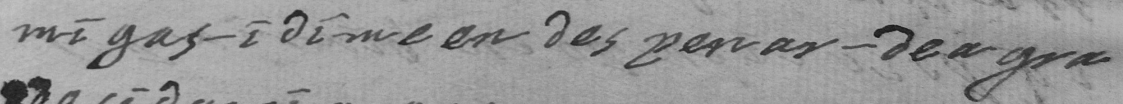

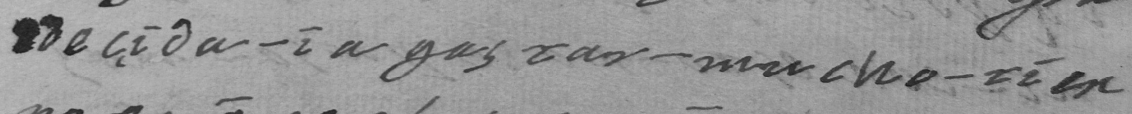
poten quer last por q alserozen

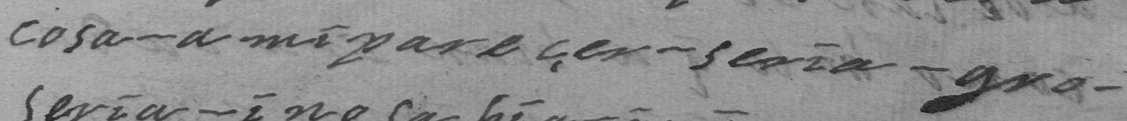

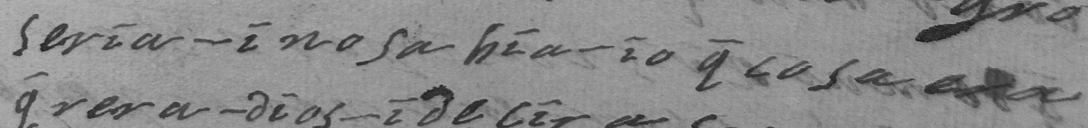

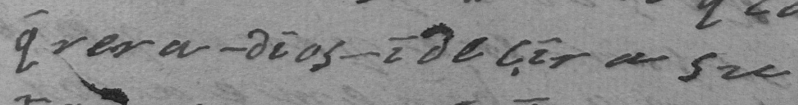

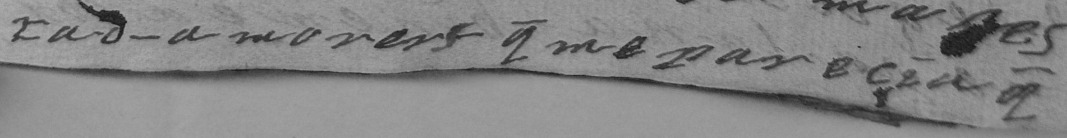

$\mathrm{N}^{\circ} 9,2010$, pp. 73-120

81 
Un rasgo característico de su escritura es que no respeta en absoluto la unidad de palabra ni de sílaba, recordando así a la característica principal de la escritura cursiva de siglos anteriores, y que acostumbra a trazar pequeños guiones entre las palabras, letras o sílabas sin criterio de unidad "tubo-a gran mi la gro-el no-mal logra".

En cuanto a las abreviaturas, no son frecuentes, pero destaca el uso continuo de la abreviatura de "que" con una "q" sola con su "-" encima.

\section{EL TEXTO ORIGINAL FRENTE AL CORREGIDO PUBLICADO}

Si algo destacan los distintos autores ${ }^{16}$ que han profundizado desde uno $\mathrm{u}$ otro campo de estudio en este tipo de autobiografías de religiosas es la doble condición de ser un vehículo de conocimiento de la voz femenina al tiempo que no es un testimonio fresco y directo de la voz de la mujer sino un producto matizado por la censura o simplemente la sombra de la jerarquía eclesiástica al ser estas religiosas orientadas por sus confesores ${ }^{17}$. En la Vida de Mauricia los paralelismos retóricos y el uso premeditado de fórmulas recurrentes así como una cadencia estructural de ritmo son claras y coincidentes con los de otras compañeras suyas, independientemente de las diferencias en sus vidas.

Esa retórica, fórmulas estereotipadas y esa estructura, están ya en el original, puesto que en efecto Sor Mauricia escribe -así lo dice- por obediencia y por lo tanto además de estar inmersa en el marco ideológico de su época y de su condición de religiosa, ya lo hace "guiada" . Aún así, la versión original muestra una voz que aunque sometida, no puede sustraerse a la frescura de expresiones que se muestran propias y expontáneas.

La aportación más valiosa de estos manuscritos es que permite contrastar el contenido directo de la versión original, con el contenido de la versión publicada. La constatación de sus modificaciones y censuras permiten no solo valorar esta autobiografía sino calibrar cual podía ser en general ese calado en otras tantas .

16 A. LAVRIN, L, Rosalva (Eds.) (2002) La escritura femenina en la espiritualidad barroca novohispana. Siglos XVII y XVIII; M. DiAZ-DiocARETZ, I.M. ZAVALA, M.M.CARRIÓN, (2000) Breve historia feminista ..., ob.cit., p.222. HERPOEL, S, (1995) «Inés de la Encarnación y la autobiografía por mandato» AIH, Actas XII, pp. 284-291; LAVRIN, A, y Rosalva LORETO (Ed.) (2006) Diálogos espirituales. Manuscritos femeninos hispanoamericanos, siglos XVI-XIX.

${ }^{17}$ M. Diaz-Diocaretz, I. M. Zavala, MM CARRión, Breve historia feminista..., ob. cit.; S. HERPOEL, «Inés de la Encarnación...», ob. cit. 
La inmensa mayoría son pequeñas correcciones de estilo, tantas y tan salpicadas que no consideramos labor de este tipo de estudio el resaltarlas. Otras, más extensas están pensadas para cortar lo que podríamos llamar excesos expresivos de nuestra protagonista, porque, sin duda, si algo tenía la hermana Mauricia del Santísimo Sacramento era una expresividad desbordante, tanto en sus referencias religiosas como en su forma de redactar sus propios sentimientos y lo que le ocurría. Ejemplos de ello son párrafos como los que siguen:

La copia impresa corregida dice ${ }^{19}$ :

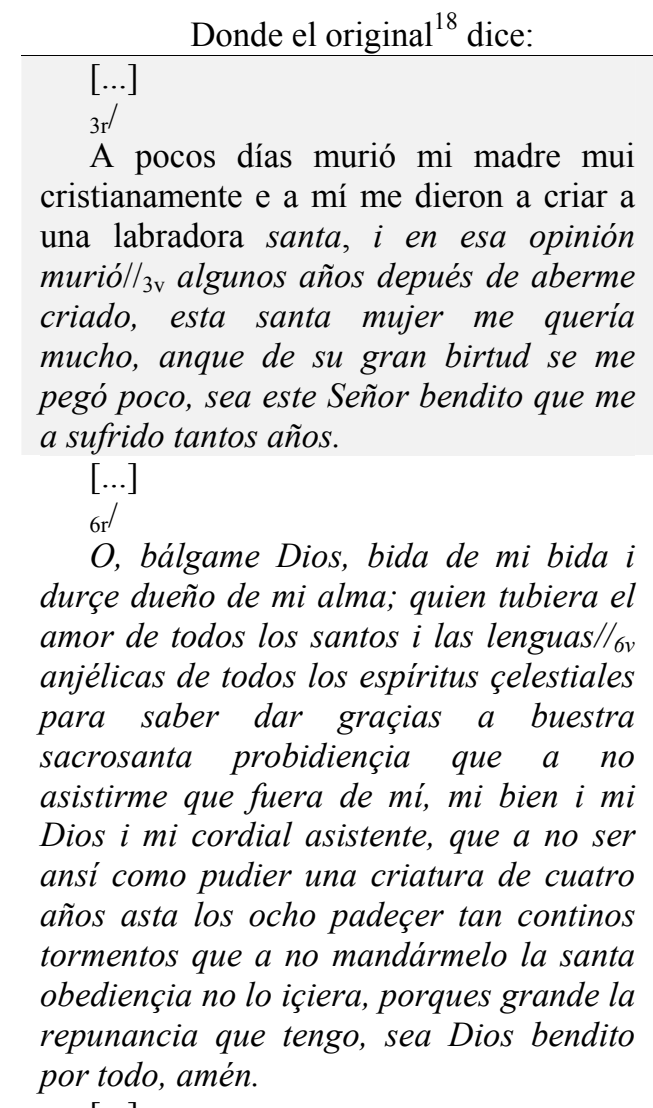

$3 \mathrm{r}$ ristianamente e a mí me dieron a criar a una labradora santa, $i$ en esa opinión murió// ${ }_{3 \mathrm{v}}$ algunos años depués de aberme criado, esta santa mujer me quería mucho, anque de su gran birtud se me pegó poco, sea este Señor bendito que me

[...]

O, balgame Dios, bida de mi bida $i$ durçe dueño de mi alma; quien tubiera el amor de todos los santos i las lenguas//6v anjélicas de todos los espiritus çelestiales para saber dar graçias a buestra sacrosanta probidiençia que a no asistirme que fuera de mí, mi bien $i$ mi Dios i mi cordial asistente, que a no ser ansí como pudier una criatura de cuatro años asta los ocho padeçer tan continos tormentos que a no mandármelo la santa repunancia que tengo, sea Dios bendito $[\ldots]$
Dentro de pocos días, murió mi madre muy Christianamente; y a mí me dieron a criar a vna labradora que estava en opinión de Santa: murió después de averme destetado.

\section{[...]}

Padeci esto desde los quatro años hasta los ocho.

18 Tal y como haremos en la edición más adelante, siguiendo las normas de la Comisión Internacional de Diplomática respetamos la ortografía del texto original, incluyendo entre $>\ldots<$ las palabras entre renglones y $<\ldots>$ algunas de las letras que faltan, e incluso respetamos las innumerables aliteraciones que hemos aclarado en nota al pie solo en algún caso que nos pareció más necesario.

${ }^{19}$ Mantenemos la ortografía del impreso. 
A pocos meses $/ / 10 \mathrm{r}{ }^{20} / / 10 \mathrm{v}$ ia estaba gran letora. Io estaba mui congojada $i$ penosa de a dejado de leer, anque me ubiera costado mucho trabajo; teníala mucha enbidia.

Bino a berme mio padre i dije muchas mentiras, que en eso estaba bien diestra, que sabía leer i otras cosas, i no sabía nada más de que conocía las letras. Pedile un libro "A lo dibino". Enbiómele en berso. No se como fue esto que era tanto el deseo que tenía de saber leer que durmiendo me pareçía que me enseñaban, porque de día no podía, que abía mucho que açer en la çelda.

$[\ldots]$

Abía en casa una mujer por ama, que abí $<\mathrm{a}>$ sido casada. Consolábame mucho $i$ procuraba dibertirme, mas no era posible. Era mui buena, dábame mui bu<e>nos consejos i deçíame que ia no tenía remedio, que el desposado era un anjel $i$ otras cosas a este tono, que cuando biniese saliese a reçibir, $i$ le içiese mucho cariño, porque no se enojase. Io la respon $<d i>/ /_{16 r}$ que pue $<s>$ ella abía sido casada, i sabía como se abía de deçir $i$ açer, lo que me mandaba, que lo içiera ella, que lo mismo sería açerlo io. Aquí se beyan las inorançias, $i$ boberías mías. I en<ten>día que era de la misma manera que lo deçía, $i$ entendiendo esto como pasó, $16 \mathrm{v}$

$$
[\ldots . .]
$$

I como estas cosas de jugar $i$ otros biçios no quieren más que començar, i unos se llaman a otros, fueron tan puntuales en benir, que como diçen se daban las manos, $i$ el que es parte de ellos no perdía la ocasión, baliéndose del natural e de la ocasión. De esto que e
A pocos meses ya estava gran letora la muchacha, y yo la tenía grande embidia. Halleme con pesar de auer dexado de leer, aunque me huviera costado trabajo.

Fue a verme mi padre, y dixe que sabía leer, y otras cosas; y no sabía nada, más que conocer las letras: pedile vn libro espiritual, embiómele en verso. Fue tanto lo que deseé saber leer, que durmiendo me parecía me enseñavan, porque de día no podía, que auía mucho que hazer en la celda:

Auía en casa por ama vna muger casada; consolávame mucho, dándome muy buenos consejos:

Como el juego llama a otros vicios, me fue tratando mal de palabra, y de obra.

${ }^{20}$ Recto de la página en blanco 
dicho, la tomó mi marido para tra//18r tarme mal, asi de palabra como de obra.

$[\ldots]$

I él benía de la casa del juego, que no pareçía que benía en sí, ni era, a mí pareçer, señor de sus açiones. Otra persona ablaba por él, bíase claro por lo

De la casa de juego, se conocía que no iva en// en sí, y que otro hablava por él, por los singulares movimientos que con los labios hazía, que açíal/ ${ }_{18 \mathrm{v}}$ i meneos con la boca.

Pero también, aunque en contadas ocasiones, hay omisión total de datos concretos, como su edad y la procedencia de sus padres y sus abuelos maternos, que tienen relevancia a la hora de establecer su identidad y la correcta datación de los distintos momentos de su vida. La omisión es llamativa.

\section{$+$}

En el nonbre del Santíssimo Sacramento y la lipia i pura Conçeçión de nuestra Señora, concebida sin pecado orijinal y mi glorioso padre San Agustín. Comienço a obedeçer y tratar de mi desordenada bida e ago esto a los sesenta de mi edad tan mal enpleada.

Digo que naçí en un lugar que se llama Mingela, obispado de Segobia, de padres cristianos $i^{21}$ bien naçidos por la gran bondad de Dios. Mi padre se llamó Sabastián Pérez, i mi madre Isabel de Belasco. Eran de Bizaia $i$ becinos de donde digo, porque mi aguelo trajo de Bilbao al tal $/ / 2$ v lugar que fue donde io naçí, que como digo se llamaba Mingela

\section{(Nada)}

Digo que nací en un Lugar que se llamava ${ }^{22}$ Minguela, Obispado de Segovia, de padres muy Cristianos, y bien nacidos, por la gran bondad de Dios: mi padre se llamó Sebastián Pérez, mi madre Isabel de Velasco.

Pero donde realmente sorprende la censura de la información es en el episodio de la aventura que supuso para Mauricia el viaje de Llanes a Gijón para la

21 Tachado: “...”

22 Minguela era un pueblo que pertenecía a la Diócesis de Segovia y que posteriormente pasó a ser de la de Valladolid, pero desapareció entre 1638 y 1640, quedando la zona despoblada. Tal vez por eso aunque ella dice que "se llama" la versión oficial dice "llamaba". 
inauguración. Un relato increíblemente fresco y desinhibido. El cambio en su tono narrativo es notorio, si al principio del relato el sufrimiento se hace presente, aquí se vuelve casi comedia y ella con su expresividad habitual parece celebrar lo que la versión oficial luego calla.

Es sin duda el punto más interesante de la comparación entre lo publicado y el original que aportamos. Son varias las fuentes ${ }^{23}$ que pueden contarnos como las madres recoletas llegaron a Gijón, con cuanta amabilidad se las recibió, quién lea lo que a continuación incluimos, por lo que ocurrió, por cómo lo cuenta, por el hecho de que lo hayan censurado, podrá ver un episodio que no llegó a publicarse nunca. Lo incluiremos en la edición, pero queremos resaltarlo aquí para que no pase desapercibido.

Donde el original dice:

La copia impresa corregida dice:

$[\ldots]$

Pues lo que suçedió en el camino qué pluma lo podrá deçir como fue, de qué peligros no nos libró, qué cariños acía para alentar a nuestra benerable madre $i$ a todas i si cada uno diçe de la feria como le va en ella io diré lo que me pasó, digo algo, $i$ esto era a bista de todos los que benían. Açía un sol//7v terrible $i$ como binian nuestras madres con los belos tapadas, pegabanse a los rostros que las congojaban mucho. Es berdad que en llamando a este santo prínçipe $i$ suplicándole que enbiase una nube que tenplase el calor, al instante se lebantaba un aireçito suabe con una nubeçita que se ponía delante del sol que era bendiçión de Dios, que por todo sea bendito.

Pues qué diré del>os< peligros que nos sacó. Relijiosa ubo que la derribó la caballería nuebe beçes $i$ daba con la cabeça en las piedras, que a la primera se

Pues lo que sucedió en el camino, qué pluma lo podrá contar como fué? De qué peligros nos libró? que cariños hazían para alentar a nuestra Madre, y a todas?

${ }^{23}$ M. Risco, (1795) España Sagrada, pp. 164 - 171. E. Rendueles Llanos, (1867) Historia de la villa de Gijón desde los tiempos más remotos hasta nuestros días. J. SOMOZA DE MONTSORIU, (1901) Inventario de un Jovellanista. L.SUAREZ FERNANDEZ, (1995) Reflexiones sobre la Historia de Gijón. J. Gonzalez Santos, J. López Alvarez, J. (2001) Gaspar Melchor de Jovellanos, Gijón, Apuntamientos para el Diccionario Geográfico - Histórico de Asturias. 
$>$ la $<$ podial/sr quebrar a no ser el todopoderoso el asistente en todo.

Pues qué diré de todas i de mí, que benía en un roçén tan alto como un camello $i$ inquieto más de lo que era menester, i trotaba. Pues cuando legaron los señores de la in $<$ lus $>$ tre $i$ noble billa de Jijón a reçibir a nuestra benerable madre, uno de los señores lleba $>b a<$ una iegua, ¡Dios nos libre! Cuando mi caballería la sintió, partió de carrera conmigo//8v como un raio $i$ me $<e>$ ntró por unas çarças tan espesas que se tubo a milagro patente el salir con cabeça ni ojos, i sali buen, sin que nada me içiera mal, $i$ en la caballería como si fuera un cordero, $i$ todos armirados me dieron el parabien de buena jineta, $i$ ansí me lo dijo el padre abad de Baldediós. a la bista que digo berdad que bi la muerte cuando me bi entre las çar $/ /_{9 r}$ ças. Más ia regolo mio alábete el çielo i la tierra. Quién mi bien te amara más que los más en cunbrados serafines para poder deçirlo me enseño tu sabiduría bien aquella çarçe que como si fuera una madeja de oro la iban suabiçando el rigor de sus puntas $i$ apartando unas de otras para que no me içieran el mal que justamente mereçe mi desagradeçimiento.

I todo esto era/ $g_{v}$ i es por las cordi<a>les oraçiones de esta be $<$ ne $>$ rable madre i quirida esposa tuia. Sepa todo el mundo que es piedra imán, que con lo preçioso de su gran caridad se lleba tra sí los ojos de Dios, i tenía a Su Majestad el braço de su justiçia para que no me echara por mis pecados en el infierno $i$ esto no es pasión, ni umildad sino berdad católica, como se berá el día del juiçio donde resplandeçerá la gran caridad con que Dios adornó el alma desta ben//10r dita madre i señora mía. 
Más aora, bida de mi alma $i$ durçe dueño mío, quién sino la probidiençia de Su Majestad me abia de librar de un peligro tan

Quiero bolber a atar el ilo de nuestra jornada, que creo me e dibirtido, que soi una bestia. Digo, todo lo que nos suçedió en el camino fueron profeçías, que mucho antes que suçediesen lo sabía nuestra benerable madre, $i$ los estorbos que, por lo mal que le abía de estar al demonio abía de poner e si él fuera falto de memoria, dijera io que se le abía olbidado lo que dijo el glorioso pri//10v çipe San Miguel, quien como Dios i más sabiendo que es patrón $i$ ajente de Llanes $i$ de esta dichosa casa del Santísimo Sacramento $i$ pura Conçeçión de Nuestra Señora, cuios pechos birjinales mamó este Señor de que do asta el fin del mundo siendo Dios $i$ onbre todopoderoso.

Digo que llegamos a esta insine $i$ noble billa de Jijón, bendita de Dios, $i$ todos sus santos de la Su Majestad tantas bendiçiones como tiene estrellas el çielo $i$ $<a>$ renas la mar $i$ átomos el sol. Sin pensar e dado con el sol $i$ a bista dél///1r $i$ rresplandor de sus raios $i$ de lo grande $i$ esta inlustre billa no e de açertar ablar como el santo profeta que a bista de Dios no dijo más de "aaa" mi lengua no a de açertar a deçir lo que los ojos bieron, lo grande de la nobleça, lo florido de la deboçión, lo católico de los >señores $<$ eclesiásticos i segla $>$ res $<$, lo ameno de las limosnas ${ }^{24}>$ todos sos $<$ trofeos de la caridad eran enbida cada uno $>$ su resto $<$ ${ }^{25}$ para reçibir a nuestra benerable madre
Todo lo que nos sucedió en el camino fueron profecias, que mucho antes que sucediessen las sabía nuestra Madre, y los estorvos, que por lo mal que le auía de estar al Demonio, auía de poner; y si él fuera falto de memoria, dixera yo, que se le auía olvidado lo que dixo el Glorioso Príncipe San Miguel: Quien como Dios? Y sabiendo que era Patrón, y Agente del Convento de Llanes, y desta dichosa Casa del Santísimo Sacramento, y Purísima Concepción de Nuestra Señora.

Digo que llegamos a esta insigne, y noble Villa de Gijón, bendita de Dios, y de todos sus Santos, de la su Magestad tantas bendiciones como Estrellas tiene el Cielo, $y$ arenas el Mar, y atomos el Sol. Sin pensar he dado con el Sol, y a vista, y resplandor de sus rayos, y de lo grande desta ilustre Villa, no he de poder acertar a hablar, como el Santo Profeta: mi lengua no ha de poder dezir lo grande de su nobleza, lo florido de la devoción, lo Católico de los señores Sacerdotes, y seglares, lo abundante de las limosnas: todos son trofeos de la Caridad. Eran a porfía, echado el resto para recibir a nuestra Madre para Fundadora de la Casa de sus Magestades Hijo, y Madre,

\footnotetext{
24 Tachado y oxidado.

25 Tachado y oxidado en la línea y en el interlineado inferior.
} 
para fundadora de la ${ }^{26} / / 11$ Casa de Sus Majetades, hijo i madre, donde a todas luces ai tanta deboçión, sea bendito $>$ es benerado $<$ por todo, amén.

$Y$ porque entre tanto bueno sufre una criatura tan mala como io, i por que mi inorançia a de açertar a deçir la grandeça $i$ biçarría $i$ gala del reçibimiento que esta armi $<$ ra $>$ ble billa iço a nuestra benerable madre, i porque sabido que un gran deboto de su reverenda a escrito lo que suçedió no digo nada en la matera dejando al silençio lo que no pueden deçir la lengua sino que se a deçir// donde a todas luzes ay tanta devoción. Sea bendito, y venerado por todo. Amén.

$Y$ porque entre tanto bueno sufre vna criatura tan mala como a mí, y porque mi ignorancia no ha de acertar a dezir la grandeza, bizarría, y gala del recibimiento, que esta noble Villa hizo a nuestra Madre; y porque he sabido que un gran devoto de su Reverencia a escrito lo que sucedió, no digo más en la materia, dejando al silencio lo que no puedo dezir.

\section{CONCLUSIÓN}

Los dos cuadernillos manuscritos de la caja 139 conservada en el Archivo Municipal de Gijón, son el primero y el octavo de una serie total de diez, que contienen el original autógrafo de la autobiografía por mandato de Sor Mauricia del Santísimo Sacramento, una de las monjas que llegaron desde Llanes en 1668, junto con su abadesa, a fundar el convento de las Recoletas de San Agustín de Gijón.

No cabe duda de que es siempre interesante trabajar sobre documentación original, y que dentro de ella, encontrar relatos personales es un escalón más de excepcionalidad, máxime si son mujeres que de otra forma no habrían podido dejar su huella con toda la información que eso supone. Así el hallazgo del original directo, sin censuras, de una mujer en el siglo XVII que, aunque escriba bajo obediencia y ya siendo religiosa, sometida por tanto al dictado que su propio marco ideológico le impone, relata con tal frescura su vida, su infancia y su matrimonio de absoluta tortura, su abnegación ante el maltrato, su bondad para con todos, su mentalidad religiosa, su tristeza, su alegría, su modestia, su absoluto convencimiento de haber sido objeto inmerecido de la bondad divina, es sin duda un lujo. El hecho de que su autobiografía ya estuviera publicada en la recopilación de su Orden Religiosa, no hace sino añadirle valor por permitir el contraste.

En primer lugar porque los datos censurados permiten redondear la figura de una mujer que sin duda merece ser conocida, tanto más cuanto parece que sus

${ }^{26}$ Repite "ca" 
problemas -el maltrato infantil y el posterior maltrato su matrimonio- no han perdido en absoluto vigencia, ni en el fondo, ni en la forma de producirse, ni en los mecanismos de justificación por parte del maltratador y de "perdón" por parte de la víctima, o de la aceptación -en este caso de la no aceptación- que se le supone a su entorno más inmediato. De modo que observar desde la perspectiva de género, de la sociología, piscología social o de la historia de las mentalidades, todo lo que le acontece, su mentalidad, la forma en ella y los que la rodean asumen o no lo que le ocurre, es sin duda apasionante.

Por descontado, aunque de menor relevancia, es interesante para la historia de Gijón, e incluso para la de Llanes, el conocer cómo vivieron las religiosas y los habitantes de estas villas el acontecimiento de la salida y llegada de las monjas a fundar el convento, pues sin duda el viaje en sí y sus peripecias es totalmente desconocido.

Así mismo, la historia de la Iglesia, como la de tantas otras instituciones, se nutre tanto de lo que se cuenta como sobre todo de lo que se calla o censura y sobre todo del porqué se matizan, o silencian aspectos que en principio, a nuestros ojos, parecen inocuos.

Y desde el punto de vista lingüístico y literario, es un texto sumamente interesante lleno de incorrecciones gramaticales y ortográficas así como de expresiones expontáneas del habla común plasmada sobre el papel sin apenas contención. No siendo en absoluto menor el interés que puede suscitar el poder cotejar la multitud de correcciones de estilo que se pueden rastrear al cotejar el original con el publicado por Villerino.

Dicho todo lo anterior, puesto que a través de los siglos, el testimonio directo de puño y letra de una mujer llega a nosotros así, con toda su frescura, nosotros lo editamos, sin censurárselo, sin corregir su estilo para que se pueda apreciar en toda su extensión, tan solo poniendo su "mala letra de monja" en letra de imprenta, para que cualquiera pueda acceder a él, porque sin duda merece ser conocido.

\section{EDICIÓN}

Siguiendo las normas de la Comisión Internacional de Diplomática hemos respetado la ortografía del texto original, incluyendo entre $>\ldots<$ las palabras entre renglones y <...> algunas de las letras que faltan, incluso respetando las innumerables aliteraciones que hemos aclarado en nota al pie solo en algún caso que nos pareció más necesario. 
Sor Mauricia del Santísimo Sacramento, Monja Recoleta: el original autógrafo....

\section{Llanes - Gijón. Circa 1665 - 1668}

Sor Mauricia del Santísimo Sacramento, Agustina Recoleta que acompaña a la Madre María de Santo Tomé, la fundadora de los conventos de Llanes y Gijón, a la fundación del convento de Gijón en 1668. Mujer casada antes de profesar, narra su vida desde su nacimiento, una vida llena de peripecias, marcada por el sufrimiento y el maltrato en su infancia y durante su matrimonio. Su vida fue publicada en un libro recopilatorio junto a otras autobiografías de la orden, pero estos cuadernos nos permiten conocer su relato original, libre de las correcciones y censuras de la versión oficial.

AMG. Caja 139.

(Nota): Primero Códize

$1 \mathrm{r}$

Ilustrísima madre.....

En el nonbre de toda la Santíssima Trinidad, Padre i Hijo e Espíritu Santo, y de Nuestra Señora la Birjen María conçibida sin pecado original y del glorioso pínçipe San Migel i del Santo Anjel de mi guarda, todos los santos i santas de la corte del çielo, para gloria i onrra de Dios Todo poderoso i confusón de mí misma que soi una de las más miserables criaturas que por sola su bondad me a criado i rredimido con la peçiossísima sangre i afretosa muerte de Jesucristo Nuestro Señor, a quien confieso i tengo por mi berdadero padre e señor, en nonbre de Su Majestad ago esto que sabe este Señor en cuia presençia estoi, la mortificación que es para mi alma el aber de tratar de las misericordias que an pasado por mi alma sin aber abido de mi parte más que desagradeçimientos i pecados, más cuando Dios quiere que montes de dificultades [...] rompe la santa//1v obidiençia, ansí de mis confesores como de mi benerabilissima madre i señora María de Santo Tomé, fundadora de la billa de Llanes, debajo de cuia obidiencia estoi, anque indina de besar a su reverençia i suditas los pies. I confieso i berdaderamen ${ }^{27}$ que no merezco besar la tierra que esta benerabilíssima $<$ ma $>$ dre pisa, i que por sola su gran caridad, mobida de Dios, me trajo en su crodeal ${ }^{28}$ conpañía sin ser io de probecho ni an ${ }^{29}$ para trasto biejo de casa, más de que toda esta santa cumunidad tendieran la

\footnotetext{
${ }^{27} \mathrm{Sic}$

28 Sic por "cordial"

${ }^{29} \mathrm{Sic}$
} 
bandera de la gran caridad que el que es la fuente de ella, las a dado, sea $\mathrm{Su}$ Majestad bendito por todo. Amén.//2r

En el nonbre del Santíssimo Sacramento y la lipia i pura Conçeçión de nuestra Señora, concebida sin pecado orijinal y mi glorioso padre San Agustín. Comienço a obedeçer y tratar de mi desordenada bida e ago esto a los sesenta de mi edad tan mal enpleada.

Digo que naçí en un lugar que se llama Mingela, obispado de Segobia, de padres cristianos $\mathrm{i}^{30}$ bien naçidos por la gran bondad de Dios. Mi padre se llamó Sabastián Pérez, i mi madre Isabel de Belasco. Eran de Bizaia i becinos de donde digo, por que mi aguelo trajo de Bilbao al tal $/ / 2 \mathrm{v}$ lugar que fue donde io naçí, que como digo se llamaba Mingela.

Estando $^{31}$ mi madre de parto de mí, la dio un açidente en pariendo, i como en casos semejantes, por acudir a la madre deja la criatura. A mí, acabada de naçer enbuelta en una sábana, me pusieron en una silla baja. Açertó a entrar una beçina $\mathrm{i}$ sin reparar asentose sobre mi, i estubo ansí asta que me fueron a enbolber, que estaba ia más muerta que biba. Fue el susto de todos mui grande. Pusieron sobre mí con gran deboçión una correa de mi glorioso padre San Agustín, de quien mi buen padre era mui deboto, que desde entonçes començó este gran santo i padre mío açer mer $/ /_{3 \mathrm{r}}$ çedes i traerme subre sus onbos como si io ubiera de ser de algún probecho para algo. O Dios infinito, cuios juiçios son armirables, Vuestra Majestad Real sabe cuán gran confusión es para mí, siendo la que soi, tratar de esto, más ágase en mí buestra sacrosanta boluntad, pues estando casi aogada dio Buestra Majestad liçencia a la bida para que io la tubiese i me bautiçasen. A pocos días murió mi madre mui cristianamente e a mí me dieron a criar a una labradora santa, i en esa opinión murió///3v algunos años depués de aberme criado, esta santa mujer me quería mucho, anque de su gran birtud se me pegó poco, sea este Señor bendito que me a sufrido tantos años.

En este tienpo estaba mi padre a estudiar a Salamanca. Dio orden para que me trajesen a casa i me entregasen a una mujer de gobierno para que me criara $\mathrm{i}$ regalara como hija única de la casa de mi padre, que no se casó por que fue de la ilesia i muy gran teólogo i catreático de Prima.

\footnotetext{
${ }^{30}$ Tachado: “...”

${ }^{31}$ Corregido sobre "En"
} 
Içose como lo abía ordenado. Trájeme $\mathrm{m}^{32} \mathrm{mi}$ ama con artas lágrimas, io no lloré pocas, que la quería mu $<$ cho $>/ / 4 \mathrm{r}$ e nos pagamos con la misma mon $<\mathrm{e}>$ da $\mathrm{p}<\mathrm{er}>\mathrm{o}$ como io era de cuatro años no podía açe $<\mathrm{r}>$ lo que quisiera.A al fin io quedé $\mathrm{e}<\mathrm{n}>$ poder $\mathrm{de}<\mathrm{s}>$ ta mujer que e dicho era arto buena, anque tenía su pedaço de condiçión, i la sabiduría de Dios es infinita i sabía Su Majetad la que io era i abía de ser ordenó que todo fuese diferente de lo que mi buen padre i señor pe $<$ n $>$ saba i abía ordenado, sea Dios bendito por todo amén.

Començó esta mujer a tratarme ta $<\mathrm{n}>$ mal que, a no resplandeçer la unipotençia de Dios por solo ser quien es, fuera inposible $/ /_{4 \mathrm{v}}$ anque tubiera muchas bidas, a no ser Dios el conserbado $<\mathrm{r}>$ de la que Su Majetad me bía dado, todas dejaran de serlo a bista de tantos dolores i tromentos, todos como ella confesó después, ençitados del demonio que la atromentaba porque me quitase la bida. Io nunca la bía la cara alegre, sino cuando me llamaba para açer alguna crueldad conmigo, que eran las que diré: tomaba una toallic ${ }^{33}$ a i una albornia de Talabera $\mathrm{i}$ un cuchillo mui bien amolado i tiniéndola en las manos me llamaba, decía que sacase la lengua que me la quería cortar, i io, que sienpre la estaba tenblando, açía lo que me mandaba; sacábala i ella la tomaba con la mano i cuando//5r abía de cortarla, sentía io que se la quitaban de la mano, anque no bía yo quien esto $10^{34}$ iço, alguna $<\mathrm{s}>$ beçes en diferestes $^{35}$ tienpos i nu $<\mathrm{n}>$ ca pudo salir con su intento ${ }^{36}$ i echaba por otro camino. I eran tantos los açotes que me daba que me dejaba por muerta; i sin comer muchas beçes; i si me daba un poco de pan era mui duro i eso tirado como a un perro, que ansí me llamaba. E un $<\mathrm{a}>$ bez me quemó en la lunbre con tanta cólera que me abrasó una pierneçica que la tube para perder ${ }^{37}$ si no me curan con tanto cuidado. I io no sabía más callar i padeçer $/ /_{5 \mathrm{v}}$ lo uno porque no tenía quien me quejar, i el otro porque me matara, que lo içiera si Dios no determinara otra cosa, que por sola su bondad me pareçía que estaba conmigo. El regalo que tube en esta conbeleçiençia fue como para mí, porque me metió entre unos colchones para aogarme, después de aberme dado tantos açotes que no abía quedado cosa sana en mi cuerpo, io no se como bibía; cuando bio que lo estaba, me llebó a un poço i arrojándome en él, al caer, digo antes de caer, me pareçe que me tubieron en el aire i caí de la otra parte del brocal, i estube allí asta que ella bolbió, que pasó buen ra//6r to. El alibio que

\footnotetext{
32 Sic por "trájome"

${ }^{33}$ Escribe "c sobre t"

34 Repite "lo"

35 Sic por "diferentes"

${ }^{36}$ Tachado "porque"

37 Tachado: "que"
} 
tobe después de esto fue meterme çe $\mathrm{e}^{38}$ un aposento i de allí a un poco entró con una sotana larga $i$ un bonete $i$ el rostro mui neg $<r>0$ i las manos, i açiendo muchos bisajes con la boca i el cuerpo, diçiendo que quiría comer, diçiendo que era $>\mathrm{el}<$ diablo, traiéndome de una parte a otra pareçe que debía de querer que pues no me mataba nada de lo que intentaba me espartara ${ }^{39}$.

O, bálgame Dios, bida de mi bida i durçe dueño de mi alma; quien tubiera el amor de todos los santos i las lenguas $/ /_{6 \mathrm{v}}$ anjélicas de todos los espíritus çelestiales para saber dar graçias a buestra sacrosanta probidiençia que a no asistirme que fuera de mí, mi bien i mi Dios i mi cordial asistente, que a no ser ansí como pudier una criatura de cuatro años asta los ocho padeçer tan continos tormentos que a no mandármelo la santa obediençia no lo içiera, porques grande la repunancia que tengo, sea Dios bendito por todo, amén.

Acabo de este tienpo que digo, bino mi padre abiendo acabado sus estudios que como digo tenía ya $8^{40}$ años. Como el rregalo no abía sido como pensaba io estaba tan desmejorada $/ /_{7 \mathrm{r}}$ porque no lo debían escribir. Ansí sintiolo mucho i io no me atrebí a deçir nana ${ }^{41}$ de miedo no me matase cuando mi padre saliese de casa, anque la tentaçión no se la quitó por aber benido. Más ordenó Dios, que es el alibio en toda mi bida $i$ alma, que sin deçir io nana a mí padre por lo que tego ${ }^{42}$ dicho bino a saber algo, con que dándola lo que se la debía, se fue con Dios, e io quedé con el desaogo que se puede creer, i con temor si abía de ser ansí otra ama que abía benido. I no fue como io lo temía, porque me quería mucho i me daba de comer i todo lo demás a su//7v tienpo.

Mostró el querer darme gusto, io le tenía mui gra $<\mathrm{n}>$ de en oír misa, anque asta allí no abía echo más que padeçer como una bestiçuela, porque io no sabía que era deboçión ni açer aplicaçión a Dios de nada. Con todo eso en uiendo misa, e biendo a Nuestro Señor sacramentado, no sé qué sentía dentro de mí, que diera mil bidas por aquel Señor que abía bisto; i era tanto que deçía que si a la puerta de casa o de la ilesia se pusieran muchas espadas a estorbarme la entrada, me entraría por todas. Tenía unas enorançias bobas, e como el serlo cuesta tan poco, eran estas inorançias para lo malo, muchas e no aprobechaba i balía nada para lo bueno. Io quedé tan poco//8r debota ni cariñosa a los açotes i malos tratamientos del cuerpo por mi mal

\footnotetext{
${ }^{38}$ Sic por "en"

${ }^{39}$ Sic por "espantara"

${ }^{40} \mathrm{Sic}$.

41 Sic por "nada"

42 Tachado "n"
} 
natular ${ }^{43}$ i medrosa de lo dicho, que en toda mi bida como se berá, los pude açer cara i oirlos mentar, sin gran mortificaçión de mi alma, que es arta confusión para ella el ber las penitençias que $>$ a $<$ çen los amadores de Cristo, Nuestro Señor, i de su santçissima +. Sea bendito $\mathrm{Su}$ Majestad, i su paçienc $<\mathrm{i}>\mathrm{a}$ sacrosanta que me sufre tantos años, siendo la que soi, por so la su bondad, pues sabe este Señor todopoderoso que el menor desacato que io la más desagradeçida i bil criatura $>$ açía $<$, mereçía $/ /_{8 \mathrm{v}}$ trenta mil infiernos a no mirarme Su Majestad Real con ojos tan de Dios i padre sea bendito por todo, amén.

Digo que oía misa, cada día i por uirla, madrugaba i con ese cuidado me acostaba. Iba a uirla a un conbento del Santo patriarca San Françisco, poníame junto al altar maior, i solía ser tan de mañana i io era tan ruineja que el sacristán que iba a ençender la lánpara tropeçaba en mí, i con cuidado preguntaba cuia era. Ia io andaba a la[brar] i me enseñaban la dotrina, anque en to aprobechaba bien poco como era ia de $9^{44}$ años para enseñarme a todo jénero de labor blanca i leer $\mathrm{i}$ todo lo demás $/ /_{9 \mathrm{r}}$ que a menester saber una hija de jente onrrada. Llebáronme a un conbento, que io era mui inclinada a monjas i deseaba selo. Estaba ${ }^{45} \mathrm{i}$ io mui contenta i oía misa cantada cada día que para mí era gran regalo. Pareçíalas a las monjas que estaba con deboçión en el coro a los mantines i lo demás, i queriánme mucho. Era apaçible i no jugetona, que nunca lo fuí, i era muy amiga de dar guto que en ocasiones açe arto daño. Era conpasiba, mucho, no me acuerdo en toda mi bida abé dejado de llorar en biendo llorar a cualquiera persona ni dejar de sentir su pena más $/ /_{9 v}$ que las mías. Açía cuanto podía an $<$ que $>$ me costase mucha pesadubre, porque deçía que las penas i trabajos solo io los mereçía, i esto $>$ no $<$ lo açía de birtud sino de inclinaçión, pues con esto bine a tener amigas que e sido gran persona de $>$ es $<$ to y de ser mui fiel a la amistad, tiniendo por afrenta lo contrario.

En es $<$ te $>$ tienpo estaba en este conbento una niña de mi edad, a lo mismo que io, fuimos mui amigas i a ella la enseñaba a leer la monja que la tenía por su cuenta, i si no sabía la liçión dábala pellizcos, que io por lo que tengo de espiriençia del manjar que es, por lo que tengo dicho arriba, no los podía ber. I así dije que no quería saber leer, i así no me lo enseñaron. A pocos meses $/ /{ }_{10 \mathrm{r}}$ (Página en blanco). $/ /_{10 \mathrm{v}}$ ia estaba gran letora. Io estaba mui congojada i penosa de a dejado de leer, anque me ubiera costado mucho trabajo; teníala mucha enbidia. Bino a berme mio padre i dije muchas mentiras, que en eso estaba bien diestra, que sabía leer i otras cosas, i no sabía nada más de que conocía las letras. Pedile un libro "A

\footnotetext{
43 Sic por "natural"

${ }^{44} \mathrm{Sic}$.

${ }^{45}$ Tachado: ."..."
} 
lo dibino". Enbiómele en berso. No se como fue esto que era tanto el deseo que tenía de saber leer que durmiendo me pareçía que me enseñaban, porque de día no podía, que abía mucho que açer en la çelda. En e//11r feto, sin aberme enseñado, estaba más letora que ella, i en latín, con armiraçión de todas. Con esto i el gusto que io las daba, quedar el era mi inclinaçión propia, me querían que no abía otra cosa, i como me bían tan en las cosas de la relijión, pensaban que era buena. Nunca estaba oçiosa, i todo aiudaba a pareçerlo, i a mí no me pesaba de que lo pensase $<\mathrm{n}>$. Començé a tener amigas, $\mathrm{i}$ dime en despenar de agradeçida, $\mathrm{i}$ a gastar mucho tienpo en quererlas, porque açer otra cosa a mi pareçer sería grosería. I no sabía io que cosa era querer a Dios i deçir a Su Majestad amorers ${ }^{46}$ que me pareçía que $/ 1_{11 v}$ era atrebimiento i que no se podían deçir a quien no ablaba. Destas inorançias tenía muchas, como se berá.

Ia abía dicho io que sería monja, que pensaba que serlo no era más que querer bien, i como io era tan amorosa de mi natular ${ }^{47}$, pareçíame que estaba todo echo. En este tiempo bino mi padre a berme. Dijéronselo, que io no dije nada, e dio su raçón de que abía de ser casada i que poco tienpo enbiaría por mí. Con esto no se pasó más adelante en este caso. Io, como bi lo que abían tratado, quedé mui triste, i pareçiendome que el casar era para ponerme galana, bíneme a con $/ /_{12 \mathrm{r}}$ solarme, que, si $>$ su $<$ piera lo que era io $>$ no $<$ me casara por todo el mundo. Mas el todopoderoso, que lo ordenó, sabe para qué. Sea bendito por todo, amén.

En este tienpo leía io en ${ }^{48}$ un libro mui deboto, de la bida de Nuestra Señora, i a mí pareçíame todos los desposados abían de ser como estaba escrito que era el santíssimo patriarca San Joseph, i como me deçían que las donçellas no traían galas asta que se casaban, para esto entendí que era el casarse. I sí io deçía a Nuestro Señor que pues me abía de casar, no fuese el marido mui moço, i que en todo fuese mui atento ${ }^{49} \mathrm{i}$ bien enten $>\mathrm{di}<\mathrm{do}$ i bien $/ /_{12 \mathrm{v}}$ acondiçionado, porque era mui opuesta, $\mathrm{i}$ lo soi, a malas condiçine ${ }^{50}$, por lo que queda dicho arriba, i que no juase ${ }^{51}$. Estas boberías i otras, deçía todas a mi modo. ¡O bida mía, alabe a buestra Majestad el çielo i la tierra por paçiencia i misericordia con que me sufrido buestra infinita bondad, que sin responderme lo que io mereçía se iço buestra sacrosanta boluntad,

\footnotetext{
${ }^{46}$ Sic por "amores"

47 Sic por "natural"

48 Tachado "mu"

${ }^{49}$ Repite "aten"

${ }^{50}$ Sic por "condiciones"

${ }^{51}$ Sic por "jugase"
} 
i por las birjinales encrañas ${ }^{52}$ en que andubistis i cuantas gotas de leche mamastes que tantas merçedes echas con buestra acostunbrada misericordia//13r echas por so la buestra bondad, por ser buestra Majestad quien es, no las pierda io por ser la que soi!

Al fin me casó mi padre, i todas mis petiçiones fuer $<0>$ n como mías porque todo fue al rebés de como io quería, sino una que era que fuese bien naçido, que lo era mucho, lo demás, como Dios sabe, anque era mui cristiano i tenía mucha caridad con todos i más conmigo, si io supiera conoçerlo i estimar i conoçer el tesoro de los trabajos llebados pora amor $>$ de $<$ Dios. Más todo era bachillerías bobas las que io tenía i balíame de la//13v raçón, me pareçía que la tenía. Decía que Dios no quería disparates i no miraba que el maior era no dejar açer a Su Majestad en mí lo que fuese su sacrosanta boluntad, que era que io no malograra sus dones. Como io soi tan ruin, no miraba lo que me estaba tan bien. Casome mi padre, como digo. Llebáronme a una aldea donde a la saçón estaba, porque tenía su açienda i como io era sola i mi padre tenía lo que abía mester i esta aldea era suia, i no quería que el marido me llebase a otra parte por lo mucho que me quería, por eso me casó con este mançebo// ${ }_{14 \mathrm{r}}$ (página en blanco) $/ /_{14 \mathrm{v}}$ pobre, mas bién naçido co $<$ mo $>$ dejo dicho.

Cuando io llegé a la aldea i bi la cama que tenían echa, pregunté que para quién era $<a>$ aque lla $<$ cama $>$ de respeto. Me respondió el ama, que era para el desposado i para mí. No sabré deçir lo que mi coraçón sintió; solo diré que si me enterran biba no lo sintiera más. Todo era llorar mi poca suerte. En tres días enteros, no era otra más que echa agua de mis ojos, que mejor dijera que eran ríos. En $\mathrm{e}^{53}$ sta ocasión no abía benido el desposado, que no bino conmigo porque fue a un negoçio suio $/ /_{15 \mathrm{r}}$ (Página en blanco) $/ /_{15 \mathrm{v}}$ anque io no deçía nada $<\mathrm{a}>$ mi padre por no darle pena, i cuando abía de comer u çenar como no me bía, preguntaba por mí; io, por escusanme decía mil mentiras i açía que mintise $<\mathrm{n}>$ todos. Abía en casa una mujer por ama, que abí $<$ a $>$ sido casada. Consolábame mucho i procuraba dibertirme, mas no era posible. Era mui buena, dábame mui bu<e>nos consejos i deçíame que ia no tenía remedio, que el desposado era un anjel i otras cosas a este tono, que cuando biniese saliese a reçibir, i le içiese mucho cariño, porque no se enojase. Io la respon $<\mathrm{di}>/ /{ }_{16 r}$ que pue $<\mathrm{s}>$ ella abía sido casada, i sabía como se abía de deçir i açer, lo que me mandaba, que lo içiera ella, que lo mismo sería açerlo io. Aquí se beyan las inorançias, i boberías mías. I en<ten>día que era de la misma manera que lo deçía, i entendiendo esto como pasó, mi padre por una parte se

\footnotetext{
52 Sic por "entrañas"

53 Repite "e"
} 
celebró el dicho, i por otra le llegó al alma el berme con tan poco gusto, i como era criatura, pareçíales que con el cariño del desposado no sería nada más mi cora $>$ çón $<$, sienpre me profeçitó la berdad como aora diré, sea Dios i todo mi bien bendito por todo, amén $/ / 16 \mathrm{v}$

Al fin, bino el despasado ${ }^{54}$, mui cariñoso. Io, a fuerça de lo que me abían dicho lo mostré estar, anque paraçía ${ }^{55}$ que lo abía buscado prestado. Ansí como le bí, le conoçí el natural, como si le ubiera tratado toda mi bida, que está misiricordia con todas las demás de conoçer los naturales me a echo Dios por so la su bondad. Pasáronse algunos días, anque pocos, al pareçer con gusto, anque io no le tenía i podía anque açía todo lo que podía de mi parte por no dar pena a mi padre, que $\mathrm{se}<\mathrm{n}>$ tía mucho que io no le tubiese. Por es $<$ te $>$ tienpo acían fiestas a la degollación de señor San Juan ${ }^{56} / / 17 \mathrm{r}$ i como en estas ocasi<0 $>$ nes se suele gugar, toda la fiesta paró en juego. Olgáronse mucho porque el desposado lo sabía açer bien, los que le llebaban el dinero quedaron mui amigos, los afiçionados i el que era amigo de pagar en la misma moneda, tanbién. Besitábanse a menudo, i como el aber dinero es la mejor ocasión, balíanse de ella e jugaban, que no abía más que pedir. Mi marido sienpre perdía, decían que porque no tenía maliçia i fu ${ }^{57} 11$ ería, i que trataba mucha berdad; i sería ansí porque jamás ganaba, i por desquitarse perdía más. Conque en poco tienpo se echo de ber su/ $/{ }_{17 \mathrm{v}}$ poca suerte en jugar. I la berdad de mi coraçón, como adelante se dirá, todo esto no me atrebía io a decir nada a mi padre, a él tanpoco porque no daba lugar a eso, porque como digo, la condiçión no era para dejarse llebar, i más de una muchacha anque por la bondad de Dios nunca le dije nada que no le estubiese mui bien. I como estas cosas de jugar i otros biçios no quieren más que començar, i unos se llaman a otros, fueron tan puntuales en benir, que como diçen se daban las manos, i el que es parte de ellos no perdía la ocasión, baliéndose del natural e de la ocasión. De esto que e dicho, la tomó mi marido para tra $/ /_{18 \mathrm{r}}$ tarme mal, así de palabra como de obra. Este era un jénero de tormento sobre lo pasado para mí, que no aí palabras para deçirlo. Mi defensa era llorar. Ibame con Nuestro Señor i deçía a Su Majestad mil boberías: que no era aquello lo que io le suplicaba; que no me abía entendido, pues todo abía sido al rebés. I esto era sin ablar palabra, porque no podía de la pena que me pareçía que me aogaba, i el alibio de ella eran otras muchas por la continaçión de lo que tengo dicho. I él benía de la casa del juego, que no pareçía que benía en sí, ni era, a mí pareçer, señor de sus açiones. Otra persona ablaba por él, bíase claro por

\footnotetext{
${ }^{54}$ Sic por "desposado"

55 Sic por "pareçía"

${ }^{56} 29$ de agosto

${ }^{57}$ Tachado "l"
} 
lo que açía//18v i meneos con la boca. Todo lo tiraba; nada le daba gusto en casa. Si abía lunbre reñía porque la abía, si no porque era poca. De todo era esto mismo. Si benía a las doçe de la noche, que cuando era a esta ora era tenp $<r>$ ano, si estaba la puerta çerrada me mataba a puñaços, que del primero me dejaba sin sentido, con tan malas palabras que del todo quedaba sin él. Decía, que si alguien le benía a matar, sin saberlo él que por qué abía destar çerrada la puerta de su casa i que por qué no le estaban aguardando le detrás de la puerta para que no llamara.

E $s<i>$ otra noche, escarmentada de la pasada//19r tomaba la lición que me bía dado i con arto miedo de que no me quebrase la cabeça, que la tenía bien doloría, i ésta $<$ ba $>$, aguardando a la puerta para abrir al punto como estaba con tanto cuidado, en sintiéndole benir por el patio que ia llegaba, abría la puerta, pues era mucho peor. Entendí que me matara, diciendo que, pues estaba tan a punto para abrir la puerta que esperaba alguien de mi gusto i no me dejaba gueso sano, $¡ \mathrm{O}$ bida de mi alma, Dios eterno i durçe i cordial pítima de mi bida. Que ${ }^{58}$ no conserbar Buestra Majestad la que $/{ }_{19 \mathrm{v}}$ me a dado por so la su bondad i misericorida infinita, que ubiera sido de mí en tan gran jénero de tribulaçiones, sea Buestra Real Majestad bendito por todo, amén.

Al fin, los naipes dieron prinçipio para todo mi desconsuelo i fin a toda mi açienda, que antes de berme rica, que deçían que lo era, me bi tan probe como diré. Abíame dado mi padre buen cantidad de todo cuando me puso en mi casa, que, como digo, apenas supe qué cosa era el tenerla por lo dicho, cuando me suçedió lo que diré.

Toda la jente me tenían//20r lástima porque me querían mucho. Io açía por todos lo que podía. Tenía muchas amigas, consolábanme diçiendome que si Dios me diera hijos, sería de descanso para mí, i que mi enportaría mucho para que mi marido no jugara tanto, porque anque mi padre le deçi lo que le estaba bien i otros no serbía de nada, más que ser peor para mí. I anque no era tarde para tener hijos, porque abía poco que me abía casado, e no tenía más de 13 años, supliqueba ${ }^{59}$ a Nuestro Señor que me los diese, aunque con $/ /_{20 v}$ arta relajaçión por que no sabía si tenerlos sería peor, en esta ocasión nos conbidaron para un bautismo fuera del lugar, que ahí ia io de ser la madrina, que era subrina de mi marido la criatura, hija de un ermano suio, todos jente de porte i onrados por todos caminos. Ubo mucha fiesta. Estubimos allá $9^{60}$ días i anque ubo ocasión de jugar, no lo iço por respeto de

\footnotetext{
58 Tachado "n"

59 Sic por "suplicaba"

${ }^{60}$ Sic.
} 
su ermano, que era maior. A mí me içieron particular onra, i estaban mui contentos todos de que el casamiento ubiese sido tan a su gusto i probecho de su ermano, porque él abía labádome $>m u<$ cho diçiendo como era rrica i mui casera $/ / 21 \mathrm{r}$ i mui laborosa, entendía apacible, i otras cosas muchas en mi abono, i que me quería más que a sí. A todo esto no estaba io allé, que me abían llebado unas amigas al canpo. I tanbien dijo nada de lo que abía dicho, i lo que me quería no me lo deçía a mí, porque a la mujer propia no se la abía de deçir nada. Io tanpoco dije nada de como me trataba. Con esto tratamos de benernos a casa que abíamos de andar siete gleguas que eran de jornada. En todo el camino casi no me abló palabra. Púsosele el rostro como cuando açía aquellos des//21v afueros que dejo dicho arriba. Estábamos entre una arboleda jonto a un río que llaman Duero, çerca de un conbento de frales, más no sé io $>$ de $<$ qué orden. Al fin, él se apeó i tomándome en los braços me apeó, i en estando en el suelo, sin ablarme palabra, sacando la daga me fue a matar. Al tiempo que iba a ejecutar el golpe, le tubieren el braço en el aire i el quedó como un difunto el color. Io no bí quien se le tubo, se que de que le bí como estaba le tube mucha lástima, porque él no podía bolber en sí, anque él deçía después que era//22r señora Santa Teresa la que le abía tenido el braço, i esto io lo ui sin querer, que lo contó todo a los amigos estando en conbersación. I dijeron que si me matara que abía de açer, respondió que echarme en el río i meterse fraile en aquel conbento que estaba allí junto él. Quedó como digo tan descolorido de lo que le abía suçedido que en algunos días no pudo bolber en sí, i pareçía que estaba penoso de lo que abía echo, anque no le duró mucho el pesar pues no senmendaba. A mi pareçer era que no acía na//22v da de su parte, que abisos de Dios, artos tenía, i confesaba que no iba en su mano todo lo que açía conmigo, que bien bía él que era tentaçión del demonio, más que él no podía más. I io lo bía tanbien i le abisaba cuando le benía aquella desaforarada cólera; más no aprobechaba. Io estaba con el temor que Dios sabe, esperando la muerte, por istantes, sin más prebençión que llorar mi poca suerte. Sea bendito este Señor todopoderoso i sabio que por sola su bondad a sufrido con tanta paçiençia mis ingratitudes i poca aten $/ 23$ r çión a un Dios a quien tantas misericordias debo. Todo el çielo i la tierra alaben a Su Majestad en mi nonbre, amén.

En este tiempo que digo, a pocos días que abía suçedido lo que e dicho, me dijeron que estaba preñada aquella ama que e dicho de mi padre, que abía sido casada, que io no lo sabía más ella lo conoçió. Dijela io que no sería ansí porque io no sentía nada. Pasaron aljunos días, i estando uiendo misa, al tienpo de tocar a santos, sentí una cosita mui pequeña dentro de mí, como que se abía puesto de rodillas, adorar al santíssimo sacramento//23v que asta que naçió siempre lo iço, i era de manera que anque io me quisiera asentar, no podía asta que abían consumido a Su Majestad, i purificado el cáliz. Esto era cada día, asta que como digo, nació. I 
como io tenía tantas penas i golpes, que anque estaba de la manera que digo no me faltaban, i la criatura desde que benía de misa en todo el día no solía sentirla, dábame mucha pena si se abía muerto por mis grandes pecados. Ibame a la ilesia i al tienpo que iba açia el altar, la sentía mui mortiguadita, que me ca//24rusaba deboción, i si io fuera buena, me $>\mathrm{e}<$ nseñaba lo que abía de açer en la presençia de mi Dios i señor, que sea bendito e santificado en todas sus obras, amén. Con esto iba más consolada, anque me duraba poco, porque no se puede creer las tribulaciones i sustos que tenía por istantes, de malas palabras i castigos que estando como estaba no reparaba en tirarme lo que tenía en las manos i arrojarme por la escalera. I estando en casa de mi buen padre, estando ia de más de siete $>$ meses $<$, me trajo a casa, dándome tan grandes golpes $/ /_{24 \mathrm{v}} \mathrm{i}$ enpuçones, que se tubo a gran milagro el no malograr la criatura i quedar con bida io. Más como Dios es resurrección i bida, nada bastaba a quitarmela como se el tenerla fuera de algún probecho. Sea Su Majestad bendito por todo, amén.

Al fin llegó con estos trabajos cotinianos i otros, la ora del parto, que fue mui riguroso i duro, cuatro días con sus noches, que estube mui al cabo. Paréçeme que no sentía morime, i que si me enterraran biba no dijera nada sigún esta $<$ ba $>$ de postrada. Deçíanme que lo sentiría mi marido mucho i que açía muchas lástimas. Era bíspera del glorioso//25r i ebanjelista San Lucas ${ }^{61}$. A las onçe de la noche, tocaron a parto, io no daba i tomaba, que estaba más muerta que biba, echada en unos colchones. En esto entró una mujer que para mí no fue sino anjel. Entró preguntando adonde estaba la niña, llegose a mí con lindo ánimo y açiendome muchos cariños, me dijo que no se abía de ir de conmigo a[s]ta que pariera, alentome mucho que en todo tienpo inporta una mujer de animo $\mathrm{i}$ barol $^{62} \mathrm{i}$ tomo $>$ me $<$ en braços, púsome en el suelo i trajome andar como a una criatura, estando con un dolor más//25v grande me puse de rodillas i supliqué a nuestro Señor, me conçediese por los mereçimientos de señor San Lucas Ebanjelesta, que como digo era su bispra ${ }^{63}$, a las onçe de la nuche, acuérdome que eran tres cosas las que suplicaba a Su Majestad, la una era, que estaba una mujer junto a mi casa con gran deseo de tener ijos, que abía mucho que lo era, i no los tenía, la otra que me sacase de aquel paso, muerta o biba, la otra era en probecho del projimo. Todo se abía cumplido, en poco tienpo: la mujer a los nuebe meses parió una niña, io a las doçe i media un niño ermoso i lindo//26r i blanco como la niebe, quedé mui congojada, llebáronme a la $>$ ca $<$ ma mui aprisa. En pariendo al niño me le llebaron

${ }^{61} 17$ de octubre
${ }^{62} \mathrm{Sic}$ por "valor"
${ }^{63} \mathrm{Sic}$ por "víspera" 
mui armiradas todas de cuan lindo era, i lo sanito que estaba cuando se entendió que abía de estar mui mal tratado. Sea Dios bendito, por todo, Amén.

Usábase en aquel lugar que en pariendo, a la parida la ponían mui gala[na]. Quisieron açer conmigo lo mismo. Cuando fueron a sacar las ${ }^{64}$ joias, no allaron nada que ya estaban jugadas, i io no lo sabía. Sentilo mucho, mas con el contento del niño i diçiéndome que mi padre me dar[ía]//26v otras, disimulé todo lo que pude. El padre estaba mui contento con el hijo, mas poco enmendado en jugar i lo demás, anque fui en esta ocasión bien regalada. Pero luçíaseme mal porque tube mucho mal de pechos i no quise dar a criar el niño sino criale io. Anque el mal me duró más de nuebe meses, tenía mucha leche. Mostraba tener más animo del que tenía, porque no me le quitasen, que me pareçía que sería quitarme la bida, i a no darmela el que lo era de mí alma, i el conserbador infinito de todo lo criado, no fuera posible bibir con tanto mal como tenía. Sea este Señor i padre mío bendito por todo, amén.

Içose el bautismo i ubo mucha fiesta. Ia estaba io//27r lebantada. En este tiempo bino a bisitar el obispado el señor Don Alonso Márquez, que era obispo de la Ciudad de Segobia. Era su ilustrísima mui amigo de mi padre. Aposento $<$ se $>$ en casa asta que se acabó la bisita. Traía un jubileo. Como supo el santo señor que io estaba raçien parida i que sentía el no poder açer las dilijençias para ganar. El preguntó cuantos días abía que abía parido, dijerenle ${ }^{65}$ que tres semanas. Quiso açer a mí buen padre esa onra, i sacome a misa, confeseme con un relijioso descalço, santo Françisco, que traía con $/{ }_{27 \mathrm{v}}$ sigo. Quedé mui consolada i úbelo bien menester para poder padeçer lo que diré aora.

Anque se abía jugado tanto, no se abía llegado al ganado de bacas i ieguas, ni rropa blanca. Entre las bacas, abía una que llamaban la Jila, ésta era mui mansa, cuando las sacaban para llebarlas a la desa, salían por un corral grande i esta baca se iba por la puerta prinçipal, i entraba a donde estaba el niño en la cuna i le lamía las manitas i la cara, sin açerle el menor mal del mundo, i cuando tenía pan en ellas se le comía i lamía las migajas. A mí me causaba armiraçión//28r i enterneçía ber que un animal como una baca se sujetase a un[a] inoçençia de un niño en la cuna. Esta baca i las demás i todo el ganado se bendió para jugar, que todo lo sentí io mucho i más esta baca, cuando lo supe por lo que digo arriba. Pues abiéndo $\mathrm{ju}<\mathrm{g}>$ ado i perdido de buena manera, era bispera de año nuebo y io abía parido como e dicho bíspera de San Lucas, no me acuerdo qué año. Io estaba con tanto

\footnotetext{
${ }^{64}$ Convierte "pocas" en "joias" tachando y superponiendo las correspondientes letras.

${ }^{65}$ Sic por "dijéronle"
} 
mal en los pechos como e dicho. Entró a las doçe de la noche poco más. Io es $<$ ta $>$ ba acostada con artos dolores i el niño dormido. Díjome que me quería dar los ${ }^{66} / / 28 \mathrm{v}$ buenos años de su mano, que me lebantase. Io començé a tenblar, i asiendome de un braço me sacó de la cama i me dio con unas diçiplinas de alanbre tantos açotes que ellas se quebraron e io quedé con esto i el mal que tenía en los pechos sin aliento i tan muerta que a no me asistir Dios como a señor San Antonio Abad, era a mi pareçer inposible bibir una ora. Estando en esta agonía, quiso Dios que despertó el niño. Dijo su padre que le diese el pecho, que luego me acabaría de matar. Içe cuanto pude por ber si le podía dar de mamar, que con los dolores i susto no podía mantenerme.//29r $\mathrm{El}$, como me bio tan postrada, me dibió de tener lástima, porque se fue del aposento i no le bí asta el hotro día. Ia se be cual io podía esta, pues estando como e dicho, como pude, echos mis ojos dos fuentes, llamando a Dios que es el alibio i refujio de los tribulados i suplicando a Su Majestad, no pagase aquella inoçençia de aquel niño lo que io debía por mis pecados, estando diçiendo esto me lebanté i me puse a dar al niño de mamar, i el se quedó dormido i io llorando, i no sabía como me abía de lebantar para ir a misa por no perderla, porque no//29v supiera mi pader ${ }^{67}$ lo que abía pasado, ni naide. Pasé lo restante de la noche como pude, echa toda una llaga.

Me lebanté i fui a misa. Díjome mi padre que cómo no me ponía las joias, io respondí que todo se echaba a perder con la leche, como tenía los pechos tan malos. No me dijo más. Cuando bino mi marido tanpoco dijo nada, pareçía que estaba corrido de la $\mathrm{c}<\mathrm{r}>$ ueldad que abía echo conmigo. Io era la berguença tan grande que no era posible mirarle a la cara, asistíale i serbíale cuanto podía, que açerse serbir lo supo açer mui bien. Como se bio tan apurado de lo que era menester i no tenía ia grano//30r de trigo, i él no se atrebía a buscarlo en el lugar, por lo que le abían de deçir, porque la destruiçión de mi casa en poco tienpo abía sido mucha, detreminose a ir fuera a buscar algún remedio. Díjome que iba en casa de su ermano, que es el que dejo dicho arriba a ber si quería prestarle trigo o dinero, dejándome sin nada que comer. Paréçeme que se fiaba en que la pidiría yo a mi padre. Por no le dar pena, no lo içiera, por cuanto a $<$ el $>$ ni a naide no me atrebía a pedir nada, porque tenía fama de rica. I antes lo daba io a la jente probe//30v para senbrar sin que él lo biera, i no aguardaba a que lo pidiesen porque io deçía que si les costaba berguença el pedilo, que anque se lo diese no era açer nada por amor de Dios, cuio era todo.

${ }^{66}$ Repite "bu" al inicio de la página siguiente

${ }^{67}$ Sic por "padre" 
Al fin él se fue. Io quedé como digo, criando mi criatura, i como no tenía que dar i nunca dejaban de benir a pedir algo, así como le bier çerré la puerta, i anque benían pensaban que no estaba en casa. Desta manera estube tres días sin comer bocado ni sé io cómo pudo ser aquello, que me es de arta mortificaçión el deçirlo, por no calificar mi bobería; más era tanta mi berguença que no podía más conmigo. Cuando//31r el niño lloraba, dábale de mamar, i puníale en la cuna i meçíale i quedábase dormido asta que le ponía en linpio i le bolbía a dar el pecho que era la probidiençia de Dios, de manera que no mirando Su Majestad la que io era, sino a sola su bondad, tenía tanta leche en los pechos como si comiera una gallina. I de esta que pareçe temeridad, nunca tube escrupulo, porque todo era encogimiento $i$ temor que no osaba mirar al çielo, sigún andaba de tribulada.

De esta manera estube tres días con dos noches. Al anocheçer de la noche que se cunp $/ /_{31 \mathrm{v}}$ plian los tres, me dio deseo de salir andar un poco, con arto temor $\mathrm{i}$ neçesidad de me [...] ]er algo, llegé en casa de mi padre como que iba a berle, allé al ama tan ocupada con la jente del canpo que estaba çenando que no me detube nada, ni de berguença no ablé palabra. Dijome mi padre si quería çenar, i que como estaba el niño. Dije que estaba durmiendo i que no quería çenar. Con esto me bolbía a casa, que me pareçe que sigún mi neçesidad no abía de llegar a la mañana. El niño era milagro como estaba de lindo, tenía ia çinco meses que anque a mí me faltaba el sustento a él no le faltaba//32r el suio. Sea este Señor todopoderoso bendito por todo, amén. Pues digo que al entrar de la puerta de mi casa me dio tan grande olor de comida bien gisada que el olor conortaba ${ }^{68}$. Miré a una pare i a otra, i en una tabla que estaba en el basar allé un puchero çamorano nuebo i ençima dél un paneçico que en aquel lugar tal pan jamás se iço ni se bió. El puchero tenía unas manos i pançicas de carnero más blancas que la niebe con su caldo mui//32v bien saçonado ${ }^{69}$. Io bien sabía que en el lugar no se mataba cranero ni se amasaba aquel pan, quedé armirada de ${ }^{70}$ ber aquello, mirabalo i no me atrebía a comerlo porque no sabía como abía benido asta que me mandaron comer como al santo profeta Elías, anque no bía quien me lo mandaba. Io lo comí, e de buena gana; lo bien que me supo i sastifiço, no ai lengua que lo diga. Las de todos los espíritus anjelicales i bienabenturados quisiera io tener para saber dar graçias al obrador de tantatas ${ }^{71}$ marabillas, más Su Majestad es quien//33r es i io soi la que soi, que con esto lo digo todo. Sea Su Majestad bendito por todo, amén.

\footnotetext{
${ }^{68}$ Sic por "confortaba"

${ }^{69}$ Tachado y oxidado

${ }^{70}$ Tachado y oxidado

71 Sic por "tantas"
} 
Bino mi marido de su jornada tan sin nada como fue, antes le tubieron mui a mal que a quien le abía de sobrar mucho tubiese neçesidad de nada. Con esto se fui a enpeñar con un amigo de mi padre, saçerdote santo. Diole lo que le pidió e díjole mui bien su sentir en orden a su maior bien. Bino i, con lo que trajo, se pasó algún tienpo asta que legó el tienpo de cobrar la renta i anque nunca de una manera o de otra sienpre abía que $/ /_{33 \mathrm{v}}$ jugar. Abiendo pasado lo que e dicho como cuacrotro ${ }^{72}$ suçedió lo que diré, para que no faltase que dar a Dios, si io supiera lo que abía de açer para amar a Dios, diome Su Majestad a conoçer en la ocasión pasada, cuan açeta $\mathrm{i}$ agradable a su serbiçio era la limosna dada por su amor a jente onrada $\mathrm{i}$ encojida. Tanbién me causaba deboçión i terneça grande, cuando enpañaba el niño i le bía tan gordito, i por ser Su Majestad quién es, tan sanito, después de aber él i io pasado tanto mal, aunque de los pechos ia estaba mejor, digo que cuan de $<$ en $>$ tre las sabanillas le sacaba i me acordaba de la umanidad $/ / 34 \mathrm{r}$ de Dios onbre en los braços de su Santísima $<$ ma $>$ dre birjen antes del parto ${ }^{73}$ y en $>$ el $<$ pa $<$ r $>$ to y después del parto, esta era una consideraçión que me llebaba el alma, i sin saber lo que deçía, deçía >mil cosas< quisiera saber amar aquel niño Dios i a que la madre Birjen tanbién después de aber dado graçias a Dios como sabía, que nunca supe, echaba muchas bendiçiones a mi niño con artas lágrimas, que esas nunca me an faltado. ¡Si ubiera sabido apricarlas a mis pecados! Decían en el lugar, que con bendi $/ 34 \mathrm{v}$ çiones i lágrimas criaba mi hijo. I abía un $<\mathrm{a}>$ mujer santa, casada, i el marido no jugaba, mas era mal acondiçionado; no podía la buena mujer criar un niño que tenía por falta de leche. Io la tenía mucha lástima i la criatura me quebraba el coraçón. Tenía io cuenta cuando su marido ni el mío no estaban en casa. Iba por un corral, porque no me biesen i subía por una carrera i saltaba al suio i caía en un mura $>$ dal $<$ de basura i no me açía mal pudiendo açerme mucho por las tapias que estaban altas, entraba en su casa i artaba la criatura/ $/ 35 \mathrm{r}$ de leche. Esto lo açía cada día i no me bía naide, i tengo por çierto que si Dios me a sufrido tantos años, a sido por las bendiciones que me echaba esta santa mujer. Io queda $>$ ba $<$ mui contenta de aber dado de mamar a aquel niño por amor del niño Jesús, i su Santíssima madre i mi señor San José, que esta era mi intençión anque io no sabía açerlo como debía; i creo que anque lo açía tan a lo bobo, se serbían Sus Majestades como adelante se berá. Pues abiendo pasado algún tien $/ /_{35 \mathrm{v}}$ po abía tenido mi marido ocasión de aber cobrado un poco de di<n>ero, i como tenelo $\mathrm{i}$ jugarlo era todo uno, i perder sienpre, no abía benido a casa en todo el día. Era biernes, io abía coçido i echo otras cosas que se ofreçen en casa. Estube con arta pena de que no benía. Tenía una mujer biuda conmigo por que deçían que era

\footnotetext{
72 Sic por "cuatro"

73 Tachado "de"
} 
temeridad estar sola. Io por su condiçión no me abía determinado a tener a naide. Ia como digo tenía esta buena mujer que lo era a todas luçes. Pusímonos a belar i a las onçe bino i llamome, no por $\mathrm{mi} / / 36 \mathrm{r}$ nonbre, que este bien se me pudo olbidar porque nunca él oía, i sin ablarme palabra me tomó en braços i me pusu ${ }^{74}$ en la iegua que tenía parejada, que la trajo sin que la mujer ni io ho biéramos, i sin saber donde caminaba i atreberme ablar palabra, me llebó fuera de camino porque no le toparan si le iban a buscar, i ia que abíamos andado un rato con arto frío, porque elaba mucho i estaba el çielo raso, que era por los Santos, me dijo que me llebaba a $75 / / 36 v$ matar i abía engañado a mi padre diçiendo que le abían conbidado en un lugar para unas fiestas, i que me quería llevar allá con su liçençia. El buen señor, pensando que era como lo deçía, i que abía de llebar el niño, dijo que sí. La mujer que quedaba en casa, cuando bio que era tan trade $i^{76}$ no benía ${ }^{77}$ mos $i$ el niño lloraba pensándo que estábamos allá fue a llamarme conque se descubrió la marania. Ia se be lo que lo sintiría. Enbió a buscarle i no lle allaron//37r porque abía ido como digo sin camino, que en todo iba buen fuera dél, i que era arta tentaçión la que le guiaba. Sea Dios bendito por todo, amén.

Digo que de esta manera andubimos toda la noche, diçiéndome que me abía de matar, i en toda ella no açertó con la muerte porque que el es Bida no la dio liçençia. Io esta $<\mathrm{ba}>\mathrm{mi}$ alma en un ilo como diçen. Al amaneçer me allé en una tierra que ni la //37v abía bisto ni sabía donde me estaba. Tode me daba pena. De los pechos, no podía estar. Quisiérame confesar, no abía dónde. Entre estas congojas i otras, bi que estaba junto a un río mui ameno de árboles i el mui caudaloso. Io iba pensando en señor San Antonio, que anque le e serbido poco, le e sido mui debota, pues de entre unas çarças que estaban a la marjen del río que me pareçe que era $\mathrm{in} / /_{38 \mathrm{r}}$ posible caber un onbre, beo salir un fraile françisco. Ansí como le bi quise arrojarme de la caba $<1>$ gadura, más no pude. I llegose a mí, i sin ablar me alentó diçiéndome que no temiese, que Dios estaba conmigo. No se io si le bio mi marido, suçed $<\mathrm{i}>\mathrm{o}$ lo que diré. Esto era al salir el sol. Andubimos asta las doçe, a mi pareçer por el sol que estaba al medio día, io con arta neçesidad, aunque alentada de lo que abía pasado cuando//38v beo benir açia mí a mi marido, mirando al çielo, diçiendo que le querían matar porque le amena $>$ ça $<$ ba un braço desnudo con una espada de dos filos, que si io no le defendía, sin remedio le quitarían la bida, i que cualquiera parte que iba a esconderse iba el braço i la espada, $i$ con muchas ansias me pedía que dijese io que no le matasen i que mirase al çielo para ber io lo que él

\footnotetext{
74 Sic por "puso"

75 Repite "ma" en la página siguiente"

${ }^{76}$ Borrón oxidado

${ }^{77}$ Tachados oxidados
} 
bía. Era tanta la lástima que de berle me causó que//39r por cuanto tiene el mundo no quisiera que le içieran mal; io miraba al çielo i bía nada. ${ }^{78} \mathrm{El} \mathrm{diçía} \mathrm{que} \mathrm{se}$ quitaba cuando io miraba. El se açía un mar de lágrimas; io açía todo lo que podía para consolarle, anque el natural estaba tan sin fuerças con tantas penas i la que tenía de berle ansí que no era la que menos me atormentaba. I biendome en un páramo, sin remedio porque él no traía blanca i io como me sacó como e dicho, al fin entre tantas $/ /_{39 \mathrm{v}}$ ansias se lebantó una a maiores como diçen, i me caí sin aliento, i anque oía, no podía ablar. Aquí fueron sus lágrimas, sus promesas, todo era llamar a Dios i proponer la enmienda i llame ${ }^{79}$ aún tienpo lloraba su mujer i a su hijo i a su açienda, todo esto no pareçía sino un juiçio de confusiones. Pues estando en medio dellas, quiso Dios todopoderoso i aliento de mi alma $\mathrm{i}$ todo mi bien, que bolbí en mí i mobida de sus lágrimas, açiendo todo lo que pude, començé a consolarle i asegurarle que//40r mi padre le perdonaría i que no me apartaría de él por justiçia, que esto era lo que él más temía. Començamos a caminar sin saber donde, porque él no conoçía la tierra. A poco trecho se bio un lugar en una cuesta o benta, que io no se lo que era. Io la sobí con arto trabajo. Llegamos, ia se berá como, i sin blanca i que poder enpeñar sino que io me quedara por prenda; más la probidiençia de Dios dispuso lo que diré.

La casa que bimos era taberna. Entramos.//40v Preguntó mi marido a la tabernera si tenía algo que comer, ella respondío no lo que abíamos menester, i no mui al contrario que no abía nada. Dijo mi marido: señora por amor de Dios, si quiera un par de guebos que se me está muriendo mi mujer, que todo lo que quisiere la daré. Dijo la mujer que de ninguna manera los tenía. Estando en esto entra un muchacho mudo, hijo de la misma mujer, de asta ocho años, a mi pareçer, ia digo que estaba

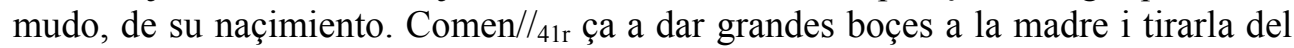
braço, que no pareçía sino que quería rebentar por ablar. La madre armirada de lo que açía el muchacho, no sabía que se açer, deçía que cuanto abía que abía naçido no abía echo tal cosa, i dando boçes como un loco, porque no le entendía la madre, la asió del abantal i la llebó al corral, señaló con la mano debajo de una manojera de sarmientos $i$ iço que se abajase i sacase unos guebos que estaban allí//4v e con su abla natural como si sienpre la ubiera tenido dijo a su madre que diera a comer aquella señora que estaba allí. Salió la buena mujer que no cabía de goço de aber bisto ablar a su hijo, dionos de comer con mucho gusto a nosotros i a la cabalgadura que la onipotençia de Dios todo lo anpara. Descansamos. Io estaba tenblando la paga que como e dicho $>$ no $<$ tenía blanca. En llegando el tienpo del partir, dijo mi marido, qué es $1 \mathrm{o} / /_{42 \mathrm{r}}$ que se debe i estando echado mano a la

\footnotetext{
78 Tachado "I"

${ }^{79} \mathrm{Sic}$
} 
fratiquera como si tubiera dinero, la mujer dijo, señor no e de tomar blanca que bien pagado está. Con esto nos despedimos i tomando raçón del camino para nuestra casa, io confundida de lo que bía bisto i la mujer armirada de lo que abía suçedido ¡O sabiduría de Dios onipotençía infinita! ¡Que es esto mi bien, mi anparo, mi refugio, aliento de mi alma i de mi bida! ${ }^{80}$ ¿Qué es esto que açe buestra Majestad!//42v iQué misericordias son estas! Açes lunbre $>$ de mis ojos $<$, echas a una bil i míserable ciratura, la más ingrata que por sola buestra bondad criasteis i redimís $<$ teis $>$ con el balor de buestra sangre i afrentosa muerte, no sea esto para maior castigo de mis pecados. Esto te suplico, señor padre mío, por el amor con que la padeçiste; sea buestro nonbre bendito por todo, amén.

Prosiguiendo nuestro camino, antes de llegar a casa, como media legua, en otro lugar se quedó mi marido//43r para que yo l'abisara de qué abía suçedi $<\mathrm{d}>\mathrm{o}$ en casa, de qué color estaba mi padre, que cuando io lle<gue $>$ fue su goço tan grande porque me juzgaba muerta, que no se puede deçir con pocas palabras. Acostaronme luego i trajeronme el niño, i regalaronme mucho, que lo abía bien menester. Mi padre me quiso apartarme i enbiar de contado por un notario a Segobia, para açer la informaçión de la mala bida que me//43v daba, ablome sobre esto de que me quería apartar, porque de otra manera no tenía remedio, porque cada día abía de ser peor, i anque io bía que era la berdad lo que me deçía mi padre, no bine en ello por la gran lástima que le tenía. Di mi raçón a mi padre i supliquele que le perdonase, i reconçiliase i trajese a su graçia. Con esto, como era tanta su caridad, con façilidad lo iço, anque con poca esperança de la enmienda, que fue bien poca o nada, como se berá. Abisele de lo que abía pasado, con eso bino i pidió perdón a mi padre.//4r Con esto se acabó esta jornada.

I como a mi ber el espíritu que se apoderaba de él por su poca resisteçia no era bueno, a pocos lançes se començó otra, i como este medio, aconsejáronle que se entretubiese en algo, porque el estar jugando sienpre le tenía mui desganado de trabajar, que no abía menester más ejerçiçio que asistir a su açienda, más en açiendose a olgar un onbre todo es traças i marañas. I así se determinó a ir fuera//44v porque quería ser notario, que tenía algunos prinçipios, que quería recorrer algunas cosas que no sabía, i esto no podía ser en el lugar. Estaba en otro como cuatro leguas de adonde estábamos, un onbre mui famoso, así en papeles como en lo demás para este ofiçio de notario, conçertose con él para lo que e dicho, por un tanto por seis meses.

${ }^{80}$ Repite "bida" 
En este tiempo traía io mui en la memoria la salida de su casa i tierra del santo patriarca Abraán $/ / 45$ que me a llebada mucha la atención este santo patriarca, i liendo su bida, lloraba artas lágrimas i deseaba mucho que me alcançara de Dios su fé, obidiençia, i espantábame mucho de que siendo tan amigo de Su Majestad le diese tantos trabajos. I traía en la memoria aquellas palabras, el Dios de Abraán, Isaq i Jacó pues estando io con estos pensamientos se acabó de efetuar que mi marido fuese aquel lugar que e dicho. Io lo sentí de muerte.//45v Mi buen padre, de pena, a pocos meses dejó la bida en sus manos, io dejandome en las de Dios, sin más discurso que una besticuela a un tienpo me allé sin padre i en tierra ajena, i con poca açienda $i$ con un marido que anque fuera mucha no era nada para gastarla en poco tienpo, como lo hiço. I fue desta manera sea Dios bendito por todo, amén.

El salió con el ofiçio de notario y sabe Dios lo que costó, i esto no fue olbidando él de jugar, porque como era maior el lugar no faltaba con quién.//46r Io enpeçé açer labor para fuera, tenía mucho que açer, que deçían que la açía buena i para pasarlo bien. Si el no jura ${ }^{81}$, no era menester más porque estaba bien reçibida i me quirían mucho, que con todas las demás merçedes que me açía Nuestro Señor, era esta $i$ que en cuantas partes estado sienpre me allegaba a lo más pinçipal de el lugar, i con esto me iba mui bien i era de mucho alibio para mí, i bueno para todo, lo que disponía Dios de mi.//46v Io estaba en un cuarto de casa de dos casados, marido i mujer, jente ançiana i mui onrrados porque mi enclinaçión sienpre fue de tratar con todo jénero de jente buena i maior, queríanme como si fuera su hija. Io les pagaba en la misma moneda, pues estando en esa conformidad, suçedió lo que diré.

No bino mi marido en todo el día a casa. Io estaba con gran pena açiendo labor. Pasose el día, era por Nuestra Señora de Agosto, bino a las 9 de la noche i no abló otra palabra mas deçir que nos fuésemos $\mathrm{a} / /_{47 \mathrm{r}}$ pasear un poco. Io dije que más tiempo era de çenar e acostarnos. El respondió que aquel era su gusto. Con esto anque io iba de mala gana, abisé a la beçina para que çerrara la puerta. Con esto io fui con él sin atreberme ablar palabra. A la salida del lugar, él alargó el paso como quién ba a açer un mal echo, io iba tenblando; i ia que estaba bien apartado del lugar en un páramo i el iba apartado de mi, bi junto a mí un onbre $i$ una $/ /_{47 \mathrm{v}}$ mujer con un niño en los braços, a caballo en un jumentillo. El onbre que iba a pie se llegó a mí i me dijo, hija buélbase a casa, i con esto se desapareçieron. Por persto que bolbí la cabeza abiendo andado lo que digo, me allé çerca de casa, i a la buena mujer que me benía a buscar echa un mar de lágrimas diçiendo que su marido ni ella no abían podido sosegar como no benía, i io benía casi sin aliento. Dijeron que

${ }^{81} \mathrm{Sic}$ 
me acostara, que ellos aguardarían a mi marido.//48r Con esto me acosté, anque no podía asigurarme.

De allí a una ora, poco más, bino cantando. A lo que después suçedeó era para sigurar a los beçinos i a mí anque io no lo estaba, porque el coraçón no le podía quietar. Recojiéronse los beçinos i él açía que se mudaba. Echose sobre la cama asta que le pareçió que todo estaba quieto, entonçes se lebantó i recojó todo lo que pudo llebar i puesto sobre la cama incó rodilla sobre mi me//48v apreta ${ }^{82}$ de la garganta de manera que no pude deçir, "Jesús" de ninguna manera, solo con el coraçón dije las primeras palabras de la Manífica de Nuestra Señora que este cántico glorioso e tenido gran deboçión e me a librado de grandes peligros como adelante se berá, pues echando mucha sangre por la boca en mi bida entede que la bida se acaba tan aprisa. Io estaba con las ansias de la muerte cuando entró la beçina con luz, e cuando 1 le//49r gó a mí i me bio a su pareçer muerta, llamó a su marido que estaba durmiendo. En esto, el mío abrió la puerta i con lo que abía recojido se fue.

La buena jente atribulada llamaron al cura e a la justiçia. Bino el cura primero, llegose a la cama, bio la sangre que estaba en ella, tomome el pulso i bio que no estaba muerta. Içieron muchos remedios, todos sobre muerta, sigún me bieron. Bino la justiçia i los beçinos $/ / 49_{v}$ dijeron lo que abía pasado i la mujer juró que tres beçes abía mirado la cruz i tantas se abía ençendido. Içose una informaçión por la bondad $<$ de $>$ Dios que sólo el ser en mi fabor tubo de desatento, que como me querían bien i no sabían la que io era, que el trato que tenía apaçible todos pesaban que era buena. El correjidor se enojó tanto con mi marido que todo lo que pudo iço para que le buscaran. Más Dios que le quería para más altos fines, no do liçençia para allarle, sea bendito por todo.//50r Quiso Su Majestad por ser quien es, que io estubie $<$ ra $>$ mejor $i$ en es $<$ te $>$ tienpo içi propósito de que si Dios me librase de aquel peligor $^{83}$, abía de tratar solo de amar a Su Majestad, i no cuidar de otra cosa, pues en $>$ es $<$ tando para poder ponerme en camino, i no bolber aquela tierra en $\mathrm{mi}$ bida como lo içe, que estando todo el mal en mí, no miraba, que adonde iba io iba todo el mal.

Digo que me detreminé a irme fiada de Dios a serbir i corriera todo por cuenta de $\mathrm{Su} / /_{50 \mathrm{v}}$ Majestad que no quería nada con el mundo, ni que nade entendiera que estaba en él en açiendo este conçierto con Nuestro Señor. I bestirme i bien labradora i bien çeudadana me fui a una çiudad bien apartada de mi tierra. Fiada

\footnotetext{
${ }^{82}$ Tachado oxidado

${ }^{83}$ Sic por "peligro"
} 
como digo en la onipotençia de Dios, en llegando lo primero que içe fue ir a tomar la bendiçión de Nuestro Señor sacramentado a la santa ilesia maior, que no se como//51r pude çertar no abiendo estado allá en mi bida. En estando con Nuestro Señor me fui a una capilla de Nuestra Señora de la linpia i pura Conçeçión, i dije a esta gran renna i señora que no me abía de ir de allí que ia sabía Su Majestad que io no abía de obrar pro mí, i ansí que biese lo que abía de açer de mí. Dije la Manífica que con esto me pareçío io abía echo todo, i sin ablar más palabra me recoji a dormir, debió de ser que otro rre//51v cojimiento no le sé. Estube ansí como una ora poco más cuando siento benir açia mí unos pasos mui queditos. Io no bolbí la cabeça asta que estaba tan junto a mí que mui quedito me dijo, señora usted quiere serbir. Io con el mismo tono dije, si señor, como la casa sea i tenga las calidades que es menester para serbir ${ }^{84}$ una mujer onrada. El que me ablaba era un estudiante que io no le abía bisto anque abía pasado lo que digo. Con esto me puse $/ / 52 \mathrm{r}$ en pie i él dijo como usted quiera ir a serbir a donde io la llebaré pida uste todo lo que quisiere i créa que no e de deçir si no lo berá ser berdad. Io le dije, señor io lo que quiero es que en la casa que e de serbir a de ser mui recojida i jente prinçipal; io no tengo de salir de casa, sino a misa, i no quisiera que fueran casados, que las bentanas solo fueran para que entrara luz. El estudiante estaba tan atento a lu que le deçía que no pareçía que cabía de contento porque era lo mis $<\mathrm{mo}>/ /_{53 \mathrm{v}}$ que él buscaba. Dijome que todo lo que io quisiese i conçertase se aría, porque en toda la çiudad no abía casa como la quél me daría, que no le abía traido Dios açaso.

A todo esto que e dicho, no abía naide en la ilesia, porque era de las doçe a las tres, que bienen los canónigos a bísp<er $>$ as. Con esto tomando la bendiçión con la fe de Nuestro Señor i su santíssima madre, me fui con el estudiante i llebome mui lejos de la çiudad al arrabal.//53r Entramos en una casa grande, i en él portal estaban unas mujeres. Estas dijeron, si iba a serbir al señor, aquela moçita que a la saçón tenía 21 años. El estudiante, por señas dibió de deçir que sí. $\operatorname{Re}<$ s $>$ pondió una mujer, qué pecados la an traido, tan niña a serbir a ese onbre. No es creible lo que io sentí, sea Dios bendito por todo, amén. Entramos en un cuarto arto bien adereçado. Estaba asentado en una silla un señor mui grabe, ia maior $/ /_{53 \mathrm{v}}$ que así como le bi me pareçío al rico abariento en majestuoso sigún le pintan en el púlpito. Díjome: sea bienbenida hija ¿De adonde es? ¿Tiene quien la conozca? Io dije: no señor ¿Pues quién la a de fiar? Porque cuando se reçibí una ama sienpre trai quien la conozca, i la fíe. Respondí io: Señor no tengo más fiador que a Dios i el tienpo; si a estos quier usted por fiadores. quedare a serbir a usted i para ber si doi gusto en lo que toca a mi obligaçión estaré un mes, i si no açertare $/$ s4r $_{\mathrm{r}}$ con lo que deseo me iré con Dios. I en tanto que esto pasaba, él estaba mirado cómo lo deçía. Dijo: ame

${ }^{84}$ Tachado 
dado tanto gusto con lo que a dicho i tanta la satisfaçión de sus palabras ija mía, que $>$ no $<$ a de salir de mi casa i a de ser dueño de todo lo que ai en ella; i ansí mire lo que la tengo de dar cada año o cada més como quisiere. Io respondí mi maior interés es saber serbir a usted. Con esto él dio una palmada en el braço de la silla $\mathrm{i}$ se lebantó mui contento, pariçiendolle//54v que abía allado lo que buscaba. A bista do todo lo que pasó estaba una ermana suia que tenía ochenta años, santa señora, abraçome con gran cariño.

El santo señor me dio el orden de lo que abía de açer açerca de su regalo, que $>$ no $<$ se trababa de otra cosa porque era mui rico. Tenía una moça para todo lo que era menester, porque io no abía de açer más que asistir como digo a su regalo i linpieça. Abía poco que abía enbiudado i enterneçiose cuando me lo dijo. Ense $/ /_{55 \mathrm{r}}$ ñome la casa que era arto linda i probida de todo regalo, porque era mui rico, $\mathrm{n}<0>$ abía naide en casa más que él i la ermana i la moça. No abía criado, que aquel estudiante no era de casa, que para mí no podía aber cosa mejor que no aber mucha jente. El silencio de la casa era grande. Io estaba contenta, i como dije al prinçipio de la misericordia de Dios de darme a conoçer los naturales, así como entré en casa i le bí, se le conoçí como si//55v le ubiera tratado toda la bida. Era este señor mui tentado de la gula, i como era tan rico i la bida tienen por la maior feliçidad i ésta les pareçe que consiste en el regalo, no tratan de otra cosa. I oir misa que esta la oía cada día. En efeto, era de las casas más regaladas, la suia, que abía en la çiudad. Diome las llabes de todo, sino la del denero, que no la quise. Para si abía menester algo, dábame unos cuartos i no era neçesario por//56r que todo lo que se podía desear, u ripedir lo abía en casa i todo lo traían sin en por ello de todo jénero de cosas. Al fin todo lo que dijo el estudiante era la berdad, i no lo dijo todo. Con esto començé a regalar con todo cuidado al señor. Traíale mui aseado. Dabale ropa límpia dos beçes cada semana, que tenía mucha i buena. Con esto, el mucho regalo, en pocos días se poso que era bendiçión de Dios. El i la ermana era de manera lo que me querían que no se puede creer. Decían a todos que ${ }^{85} / / 56 \mathrm{v}$ era benida del çielo. No me encrabagan uno ni otro que me regalara, pues lo tenía todo de mi mano, i por eso mismo comía menos. Io le daba de comer a la mesa i trinchaba la comida i açía los platos. Io estaba consolada de berme en casa tan quita sin oir juramentos ni maldiçiones, que io los e aborreçido con todas mis potençias i sentidos; no pareçía sino que estaba en el çielo. Oía misa cada día, que estaba la ilesia a la puerta//57r deçía a Nuestro Señor cuando alçaban a Su Majestad, esta sí que es bida durçe dueño de mi alma; dichosa mil beçes el alma que de tal Señor se fía. Pareçía que el alma no cabía en sí. Començé a estarme un poquito con Nuestro Señor en recojiendose la casa, i pareçeme que açía io como las moças que se dan

${ }^{85}$ Tachado "en" 
prisa açer las açiendas para irse a olgar. Así açía io, i cuando iba, pareçía que me estaba esperando Nuestro Señor, que sea bendito por $/ / 57 v$ todo, amén. Ia que abía algunos días que estaba en casa, echaba menos $\operatorname{los}^{86}$ pobres porque sobraba mucho de la mesa, i sienpre deçía el señor que se diera a que $\operatorname{los}^{87}$ a los gatos que abía cuatro bien gordos. Içe reparo en esto i pregunté a la ermana que estabamos solas: Señora, cómo no bienen probes a casa que es lástima que abiendolos se de tanta comida a los gatos" Inchiéronsela los ojos de agua i respondiome: Hija mía, artos probes aí, i bien çercanos, más no quiere mi ermano//

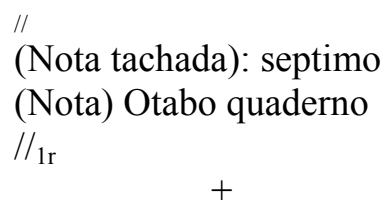

Ilustrísisma Madre

Bendeçido sea bien de mi alma sacrosanta onipotençia i sabiduría infinita $i$ probidençia. Cuando toda la cumunidad bio a un tiempo no aber çera i lugo aber tanta buena, quedaron armiradas. Io dije: Bien de mi bida, dichosa el alma que de tí se fía. Madre mía, be aquí lo que nuestro padre San Agustín diçe, que el coraçón de los tuios está en las manos de Dios, sea bendito por todo, amén. Que si se $\mathrm{u} / /_{1 \mathrm{v}}$ biera de deçir las cosas que a esta benerable madre la suçedían, fuera nunca acabar. Diré una que iço deboçión i risa a un tienpo de ber que en todo pareçía su querido i regalado esposo la quería dar gus $<$ to $>\mathrm{i}$ juntamente la mortificaba mui de lo fino como quien la tenía bien ejerçitada en todas las birtudes i en la paçieçia. Era armirable. Diçen todas las madres que la conoçieron toda su bida, que jamás la bieron enojada, i más alta la boz una bez más que otra//2r pues la caridad era sin medida i conpasiba sumamente $\mathrm{a}<\mathrm{u}>\mathrm{n}$ de los animales. Tenía gusto esta benerable madre de tener gatos por la linpieça de la casa. Pues en una ocasión que estaba mui penosa por un gato que se abía predido porque era buen caçador i abía días que faltaba, io deçía "no se perderá", no por que io lo supiera sino porque no tubiera su reverençia pena. Pues una noche díjome que dijera a santo San Antonio que trajera el ga//2vto, porque temía que le abían $\mathrm{r}<\mathrm{ob}>\mathrm{ado}$. Pues fue cosa graçiosa que teníamo $<\mathrm{s}>$ un cuadro de señor San Antonio que me le abía enbiado una amiga, i era debotíssimo i mui ermoso. Pues a la mañana estaba el gato echado junto al santo como que le tenía atado i bajando una relijosa que fue la primera que bajó al coro se le, subió a nuestra madre que se olgó mucho i dio las graçias a Dios i al

\footnotetext{
${ }^{86}$ Repite "pro"

${ }^{87}$ Tachado.
} 
santo. Io lo reí mucho, de ber que al santo padre mío tan umano que cuida//3r se no solo de la casa sino de los gatos, dijele mui amorosa olgádome mucho que íban saliendo mui a luz las misiricordias que Su Majestad açía a su sierba, i las por su infini $<$ ta $>$ bondad, açí con todas sus criaturas se bendito por todos, amén.

Pues en este tiempo estaba la benerable madre aguardando los despachos de Ubiedo para salir a la fundaçión de la inlustre billa de Jijón, que Su Majestad la estaba dando prisa. I con ser esto//3v i Dios todopoderoso primitió por sus justos juiçios que binisen los despachos no como se esperaban las liçençias por la diferencia de pareçeres, si se abían de dar en Ubiedo o en Madrid. La benerable madre lo sintió mucho i dijeronla que la era mui contrario un señor prebendado que ${ }^{88}$ a este tienpo era probisor. Pues fuese a negoçiar con Nuestro Señor como solía, i dijola Su Majestad que todo suçedía bien i que aquel que pareçía su contrario i nonbró en estando en Jijón que la tratase, la abía de aiudar i querer mucho, i con esto quedó mui consolada.//4r I como lo dijo Su Majestad ansí fue. I se dispuso la salida, anque faltó otros enbaraços porque tenían por çierto que io no benía, porque abían dicho a nuestra madre que ia que su reverençia se benía que me dejase allí como si en una ni otra parte fuera de probecho; i por consolarles abía dicho que io no benía. I io lo abía dicho, mas de Nuestro Señor, no abía teni< $<$ do $>$ io luz de que abía de benir, más abíaselo dicho a nuestra madre, que no biniese sin mí, pues es//4v tando nuestra madre con temor de lo que abían de deçir, cuando biesen lo contrario i que la una i la otra faltaban la palabra, $i$ io que tengo mucho amor propio en materia de la palabra, no sabía como salir de este enpeño, cuando interiormente sentí una fortaleça en mí que no dejara de benir aunqe me costar mill bidas. I así tomé por mi cuenta el desepeniar a mi querida madre, i dije la madre mi buen ánimo que no e de dejar de ir con su reverençia anque se unda el mundo. $/ /_{5 \mathrm{r}} \mathrm{La}$ benerabilísima madre se alentó mucho i me dijo "ermana mía no esperaba io menos de su caridad". Pues cuando se supo, dio sobre mi el raio porque en casa todas cargaron de mí. Sería largo de contar las cosas que me dijeron, que io me quería benir que nuestra madre no me lo mandaba; que i contra la obidiençia que al salir por la puerta se me abían de quebrar las piernas. No bastaba nada para sosegarlas, unas lloraban otras decían que en asentando la $/{ }_{5 \mathrm{v}}{ }^{89}$ fundaçión que abían de enbiar por mi. Todo era juiçio de Dios que açía pecado mortal en dejar mi casa i todo mi fin era a disculpar a nuestra madre, i por eso me deçían que era desobediente, i que iba contra el gusto de Dios, i otras cosas.

${ }^{88}$ Tachado oxidado

${ }^{89}$ Repite "la" 
En esto llegó una crata ${ }^{90}$ de de un santo padre benito, gran teólogo, que trató mucho tienpo a nuestra benerable madre a quíen el santo barón estima $<\mathrm{ba}>$ mucho, i la crata era para mí, que me ma $<\mathrm{n}>$ daba en el nombre de Dios que biniese con nuestra madre; conque si io tubiera $\mathrm{al} / /_{6 \mathrm{r}}$ gún esc $<\mathrm{r}>$ úpulo de benirme le quitaba del todo. Con esto me dejaron i dieron tras el fraile asta que salimos, que fue día de mi señor y pradre San Mauriçio ${ }^{91}$, que este santo fue muy debota nuestra benerable madre, i aquella mañana con todo su ejérçito de santos, mártires bino este glorioso capitán de 6mil 6 çientos i $66 i 6$ soldados que eran todos del ejéçíto i bandera de este glorioso martir, pues bino el día de su fiesta a sacar a//6v nuestra madre de Llanes para la insine billa de Jijón, i la dijo "querida i regalada esposa de Dios, Su Majestad nos enbía para que te aconpañemos en esta fundaçión que a de ser para bien de muchas almas i gloria de Dios, i tuia, porque el Todopoderoso a de ser mui serbido en ella", pues que lengua sino que sea de anjel no podrá deçir el gran número de bienabenturados i soberanos espíritus anjélicos que binieron aconpañando a su glorioso prínçipe i padre mío, señor San Miguel que benía capitaniandolos a todos como jeneral i patrón de la casa del Santisimo//7r Sacramento i de su santíssima $<$ ma $>$ dre i tan galante en Llanes i en el camino como sino no tubiera este glorioso prínçipe otra $\operatorname{cosa}>\mathrm{de}<$ que cuidar. Pues lo que suçedió en el camino qué pluma lo podrá deçir como fue, de qué peligros no nos libró, qué cariños acía para alentar a nuestra benerable madre i a todas $i$ si cada uno diçe de la feria como le va en ella io diré lo que me pasó, digo algo, i esto era a bista de todos los que benian.

Açía un sol///7v terrible i como binían nuestras madres con los belos tapadas, pegabanse a los rostros que las congojaban mucho. Es berdad que en llamando a este santo prínçipe $i$ suplicándole que enbiase una nube que tenplase el calor, al instante se lebantaba un aireçito suabe con una nubeçita que se ponia delante del sol que era bendiçión de Dios, que por todo sea bendito. Pues qué diré del $>$ os $<$ peligros que nos sacó. Relijiosa ubo que la derribó la caballería nuebe beçes $i$ daba con la cabeça en las piedras, que a la primera se $>$ la $<$ podíal/ ${ }_{8}$ quebrar a no ser el todopoderoso el asistente en todo. Pues qué diré de todas i de mí, que benía en un roçén tan alto como un camello i inquieto más de lo que era menester, $i$ trotaba. Pues cuando legaron los señores de la in $<$ lus $>$ tre i noble billa de Jijón a reçibir a nuestra benerable madre, uno de los señores lleba $>b a<$ una iegua, iDios nos libre! Cuando mi caballería la sintió, partió de carrera conmigo//8v como un raio i me <e>ntró por unas çarças tan espesas que se tubo a milagro patente el salir con cabeça ni ojos, i sali buen, sin que nada me içiera mal, i en la caballería

90 Sic por "carta"

9122 de septiembre 
como si fuera un cordero, $i$ todos armirados me dieron el parabien de buena jineta, $i$ ansí me lo dijo el padre abad de Baldediós. Más aora, bida de mi alma i durçe dueño mío, quién sino la probidiençia de Su Majestad me abía de librar de un peligro tan a la bista que digo berdad que bi la muerte cuando me bi entre las

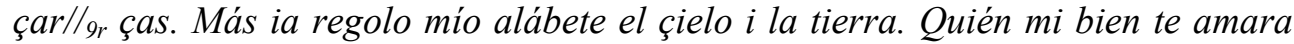
más que los más en cunbrados serafines para poder deçirlo me enseño tu sabiduría bien aquella çarçe que como si fuera una madeja de oro la iban suabiçando el rigor de sus puntas $i$ apartando unas de otras para que no me içieran el mal que justamente mereçe mi desagradeçimiento. I todo esto erall $g_{v} i$ es por las cordi $<a>$ les oraçiones de esta be $<$ ne $>$ rable madre $i$ quirida esposa tuia. Sepa todo el mundo que es piedra imán, que con lo preçioso de su gran caridad se lleba tra sí los ojos de Dios, i tenía a Su Majestad el braço de su justiçia para que no me echara por mis pecados en el infierno i esto no es pasión, ni umildad sino berdad católica, como se berá el día del juiçio donde resplandeçerá la gran caridad con que Dios adornó el alma desta ben//10r dita madre i señora mía.

Quiero bolber a atar el ilo de nuestra jornada, que creo me e dibirtido, que soi una bestia. Digo, todo lo que nos suçedió en el camino fueron profeçías, que mucho antes que suçediesen lo sabía nuestra benerable madre, i los estorbos que, por lo mal que le abía de estar al demonio abía de poner e si él fuera falto de memoria, dijera io que se le abía olbidado lo que dijo el glorioso pri//10v çipe San Miguel, quien como Dios i más sabiendo que es patrón i ajente de Llanes i de esta dichosa casa del Santísimo Sacramento i pura Conçeçión de Nuestra Señora, cuios pechos birjinales mamó este Señor de que do asta el fin del mundo siendo Dios i onbre todopoderoso, digo que llegamos a esta insine i noble billa de Jijón, bendita de Dios, i todos sus santos de la Su Majestad tantas bendiçiones como tiene estrellas el çielo i $<a>$ renas la mar i átomos el sol. Sin pensar e dado con el sol i a bista dél//1r irresplandor de sus raios i de lo grande i esta inlustre billa no e de açertar ablar como el santo profeta que a bista de Dios no dijo más de "aaa" mi lengua no a de açertar a deçir lo que los ojos bieron, lo grande de la nobleça, lo florido de la deboçión, lo católico de los $>$ señores $<$ eclesiásticos i segla $>$ res $<$, lo ameno de las limosnas ${ }^{92}>$ todos sos $<$ trofeos de la caridad eran enbida cada uno $>$ su resto $<{ }^{93}$ para reçibir a nuestra benerable madre para fundadora de $1 \mathrm{a}^{94} / / 11 \mathrm{r}$ Casa de Sus Majetades, hijo i madre, donde a todas luces ai tanta deboçión, sea bendito $>$ es benerado < por todo, amén. Y porque entre tanto bueno sufre una criatura tan mala como io, i por que mi inorançia a de açertar a deçir la grandeça i biçarría i

\footnotetext{
92 Tachado y oxidado.

93 Tachado y oxidado en la línea y en el interlineado inferior.

94 Repite "ca"
} 
gala del reçibimiento que esta armi $<$ ra $>$ ble billa iço a nuestra benerable madre, $\mathrm{i}$ porque sabido que un gran deboto de su reverenda a escrito lo que suçedió no digo nada en la matera dejando al silençio lo que no pueden deçir la lengua sino que se a $\operatorname{deçir//12r}$

Bolbiendo a las grandes misericordias i lo mucho que Dios fió de esta benerable madre, su querida i amada esposa, i la caridad tan ençendida con la que dotó, quien lo podrá deçir como fui sino el todopoderoso que se la dio para que todo el mundo goçase los frutos de ella. Qué almás no sacó de pecados, cuántas por sus oraçiones no estubieron en el purgatorio muchos años, menos que abían de estar a que erejes//12v no trajo a conoçer a Dios en las Indias, la conoçía en en Japón, la deseaban para el consuelo de los santos mártires. Dígalo por mí el glorioso prínçipe San Miguel, con otros que la aconpañaban. En Ingalaterra la beneraban i si no, digalo aquel suçeso que suçedió aun enbajador de allá que bino a Balladolid por ablar i ber la madre Santo Tomé, que está enterrado en Nuestra Señora de los Ingleses de Balladolid, que murió//13r para bibir eternamente por las oraçiones de esta balerosa madre, i por ellas le conçedió Dios tanta paçiençia i balor en sus trabajos, que fueron muchos.

Io le bisité en nonbre de nuestra madre i señora mía. No me acuerdo del nonbre. Era duque i enbajador de Ingalaterra i por que se bino a España le quitaron toda su açienda que era mucha i me dijo nuestra benereble madre que de so//13v ${ }^{95}$ los caballos, le abían quitado mucha cantidad i tratado mui mal, bino con todos estos trabajos i atropellando con todo a Madrid, donde fue reçibido como era debido a un tan leal caballero a su Dios, olgose mucho el Rei Nuestro Señor Felipe cuarto, quiso que se quedase en su corte, escusose por tener más quietud en Balladolid, i conoçer tenporalmente a la que en espíritu abía bisto algunas beçes paloma cándida, que con el $/{ }_{14 \mathrm{r}}$ durçe buelo de la caridad le abía bisto en su casa i le asistió en su muerte i no se apartó asta ponerle en el çielo. Más lo que me armiro de los juiçios de Dios, tan incomplinsibles que cuando nuestra benerable madre me mandó cuando bino este santo señor a Balladolid, cuando entré en su casa i salieron los criados, era para ber que como io no sabía la lengua todos pareçían calderos, io no los en//14v tendía, antes me congojaba el uirlos. I cuando llegé ablar al señor él me entendió con pocas palabras $i$ io a él con menos, i lluego conoçió que iba de parte de nuestra madre. No la suçedía a su reverencia lo que a mí, que su querido Esposo para esta ocasión i otras la enseño siete lenguas.

95 Repite "so" 
Estando en Llanes tubo una crata $^{96}$ de un padre de la Conpañía de Jesús en que la daba cuenta de lo que pasaba en Ingalaterra, que era de allá, en que la deçía que estaban por cuen $/ /{ }_{15 r}$ ta debajo de tierra escondidos cuatroçientos saçerdotes. Abíala dicho Nuestro Señor en algunas ocasiones que abía de bolber aquella tierra a confesar la santa fe como a sus prinçipios, ${ }^{97}$ por su bondad i oraçiones de esta benerable Virjen con que ella estaba mui consolada, cuando abía alguna buena nueba ¡Qué oraçiones! ¡Qué lágrimas! Qué mortificaçiones no la costó el çelo de dar almas a $/{ }_{15 \mathrm{v}}$ su durçe esposo i ber cunplida la restauraçión de este reino de Ingalaterra. Otras conbersiones de presonas mui prinçipales an suçedido en este reino de Ingalaterra por el socorro de las oraçiones de nuestra madre, más como no sé los nonbres ni el año, no lo digo, de un gran señor i su mujer, él fue padre de la Conpañía de Jesus i la señora monja, i esto no a mucho. Ia soi una bestia, que no e tenido cuenta con los años, anque el suçeso del enbajador en su se//16r pulcro está escrito con letras de oro en una piedra escupida ${ }^{98}$ en la pader ${ }^{99}$. No se acabará de deçir en mucho tienpo las $<\mathrm{c}>$ osas obradas del poder de Dios i caridad de esta benerable madre.

Otro caballero que se lla $<$ ma $>$ ba Don Jerónimo de Medrano que era maiordomo del Prínçipe, cardenal, estando en Toledo tubo particular llamamiento de Dios para dejar todo i tratar de su alma. Para eso se bino a Ba//16v lladolid, era santo señor, tubo notiçia nuestra madre de la intención $>$ de $<$ este buen señor, anque él andaba a lo desimulado i desenganado aiudabale nuestra madre con su oraçiónes i como Dios es fiel amigo, da sus ausilios a quien usa de ellos como debe, este señor caió en la cama del mal de la muerte, i nuestra benerable madre me mandó ir a bisitarle, tube buena ocasión porque le confesaba un gran sierbo de Dios, i io le conocía, se llamaba Frai Juan de Tanta ${ }^{100}$ María//17r bien conoçido por su gran birtud i grande maestro de letra i espiritu. Este buen padre se olgó mucho de que fuese a bisitar a este enfermo, i más cuando supo que iba de parte de nuestra benerable madre. Estube un rato con el santo caballero i ablamos de su llamamiento i de su bida, i como nuestra santa madre le encomendaba a Dios, i a mí quiso Su Majestad que las inorantes palabras que iio le díje le supiesen tan bien que no//17v quiso que me apartara de su cabeçera, $i$ ansí lo içe, que este buen padre $\mathrm{i}$ io le aiudamos a morir i nuestra benerable madre a bibir, pues no se apartó dél asta que le puso en el çielo, i no se conoçeron sino en espíritu. Acabó su bida mui católica i cristianamente como

\footnotetext{
${ }^{96}$ Sic por "carta"

97 Repite "por"

${ }^{98}$ Sic por "esculpida"

99 Sic por "pared"

100 Sic por "Santa"
} 
se a dicho. Enterrose en la Merçed Descalça donde a la saçón era perlado este santo padre que fue su confesor i testamentario. No quiso sino que le enterrasen donde todos le pisasen. De donde era este//18r santo señor me lo dijo un sobo ${ }^{101}$ criado que tenía de los más fieles i leales que bisto en mi bida.

Eran napolitanos a donde biene bien a nuestra benerable madre llamarlla madre de todos, pues esa la berdad lo es que todas las naçiones son hijas de sus lágrimas i oraçiones. I ansí se be claro lo que en una ocasión la dijo Su Majestad, día de señora Santa Jitrudes que la bino a bisitar, i la benerable madre, con su grande umildad le//18r suplicó a içiese tan agradable a sus santísimos ojos como abía echo aquella su querida esposa; i la dijo Su Majestad "María, más santa as de ser tu que mi Jitrudes" Bálgas me tu mi Dios i todo mi bien como tu bondad, lo onra i faboreçe todo. Dime, bida mía, cuando fue de estas misericordias que içiste a tus queridas i regaladas esposas la maior porque si la una fue birjen tanbien lo fue la otra, i si monja $i$ perlada, tan bien lo fue una $i$ otra, en birtud $i / /{ }_{19 r}$ mui pareçidas $i$ amabes. A una deçe in Majestad que es suia a la otra llama María que este durçe nonbre es mui del gusto de su Majestad. Más ia bida mía me pareçe que me diçe el coraçón que el deçir que nuestra benerable madre a de ser $>$ por $<$ que señora Santa Jetrudes os tiene en su coraçón niño Dios i onbre, $i$ nuestra benerable madre, Dios i onbre sacramentados pues <es $>$ cosa sabida $i$ çierta que en su puro pecho no se con//19v sumían las espeçias sacramentales de una sagrada comunión a otra, misericordia sola de buestro poder i echa a quien por buestra graçia sabe mereçerla. Sea bendito un Dios todopoderoso por todo, Amén.

Bolbiendo a deçir de la caridad > de< esta bendita madre i cómo Su Majestad la llebaba donde la ejerçitarse $>$ co $<$ mo i cuando quería, supo cuando abía de morir el señor Obispo de Ubiedo antes que lo fu//20r ese de Plasençia, i me lo dijo a mí cuando trajeron la nueba de que era Presidente. Io con aberme de estar tan bien que lo fuese por la dran ${ }^{\mathbf{1 0 2}}$ merçed que me açía no sé qué me dio que me puse mui triste i se lo dije a nuestra benerable madre, i me miró i no me dijo nada, como me bio con pena. I porque dejo dicho en otra parte lo que pasó en su muerte no digo más que aquí no solo tenía esta bene ${ }^{\mathbf{1 0 3}} / /{ }_{20 v}$ rable madre caridad con los grandes señores, ni era caridad la suia de particulares, sino para todos como la de su querido Maestro en cuia escuela abía aprendido con tanta prefeçión todas las birtudes que de solo mirarla, se conoçía que todas resplandeçían en ella. A un tienpo se allaba en los palaçios, en las carçeles, en los ospitales, en las casa

101 Sic.
102 Sic por "gran"
${ }^{103}$ Repite "ra" 
probeçitas para todos tenía consuelo porque lo que no podía remediar por sí misma porque no tenía que dar con oraçiones//21r que era los memoriales más siguros lo podía todo, $i$ lluego en biaba a los santos $i$ anjeles a consolar a los $a f i<g i>d o s$, a los enfermos, enbíaba a nuestro padre san Nicolás Tolentino. A los estudiantes i donçellas probes enbiaba a San Nicolás obispo i este glorioso santo la binía a bisitar con las presonas por quién le abía pedido unas monjas o saçerdotes. I esto antes que lo fuesen diçiendola el santo que $10 / /_{21 \mathrm{v}}{ }^{104}$ abían de ser, i io conozco agunas que io son monja i dellas son dos ermanas de padre de nuestra benerable madre, una es monja en la Madre de Dios, en Balladolid, que se llama Doña María de Posada, otra está en las Birjidas en la misma çiudad, que se llama Doña Antonia ${ }^{105}$ de Posada, otra trajo su reverenda a Llanes, que se llamaba la madre Antonia Ebanjelista, esta no es de las ermanas de nuestra benerable madre, anque en la caridad $i$ oraçiones todas lo son. Su ermana de padre $i / / 22 r$ i madre, una señora de gran sujeto i birtud que se llama Doña María Antonia de Posada, que a sido muchas beçes perlada. Io solía deçir a nuestra benerable madre que la caridad i el apellido de Posada se abían ermanado porque de todos estados allaron posada de socorro en esta benerable madre i señora mía de socorro $i$ consuelo en todo jénero de trabajos, $i$ si eran en materia que no la tubiese por espíriençia//22v como de presonas casada las enbiaba a mí, que como io lo abía sido, la pareçía la tendría en es $<$ se $>$ estado i por que naide fuese ${ }^{\mathbf{1 0 6}}$ desconosolado que asta los animalicos no sufría su gran caridad que estubiesen pues por su mano les remediaba su neçesidad.

Io confieso que me confunde el ber la bondad de Dios y por un medio tan ruin como io que soi una pacatana sacase a luz una margarita preçiosa que en la dichosa concha de su relijión e silençio se estubo esta candida paloma// 23 r asta que las notiçias de lo que a mi me abía suçedido la sacaron abo ${ }^{107}$ a bolar, cosas que se dijo en la Chançillería de Balladolid, que tal señora jamás la abían oido deçir que no es de poco consuelo para mí, como diré adelante, por a donde se be claro como esta benerable madre lo es de tos, e siendo io la que soi me reçibió por anque indina hija suia cuando rendida a los pies de Nuestro Señor i suios confieso que no merezco aber sido su esclaba, sea Dios bendito, amén. //

\footnotetext{
${ }^{104}$ Repite "abi" en la página siguiente.

105 Sic. Aunque en la versión corregida dice "Ana"

${ }^{106}$ Repite "des"

${ }^{107} \mathrm{Sic}$
} 